University of Michigan Law School University of Michigan Law School Scholarship Repository

1999

\title{
State Immunity Waivers for Suits by the United States
}

Evan H. Caminker

University of Michigan Law School, caminker@umich.edu

Available at: https://repository.law.umich.edu/articles/73

Follow this and additional works at: https://repository.law.umich.edu/articles

Part of the Constitutional Law Commons, Courts Commons, Jurisdiction Commons, and the Litigation Commons

\section{Recommended Citation}

Caminker, Evan H. "State Immunity Waivers for Suits by the United States." Mich. L. Rev. 98, no. 1 (1999): 92-137.

This Article is brought to you for free and open access by the Faculty Scholarship at University of Michigan Law School Scholarship Repository. It has been accepted for inclusion in Articles by an authorized administrator of University of Michigan Law School Scholarship Repository. For more information, please contact mlaw.repository@umich.edu. 


\title{
STATE IMMUNITY WAIVERS FOR SUITS BY THE UNITED STATES
}

\author{
Evan H. Caminker*
}

TABLE OF CONTENTS

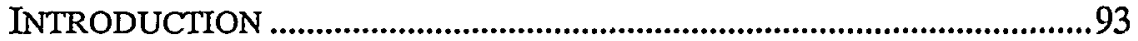

I. THE BACKGROUND PRINCIPLE OF STATE SOVEREIGN

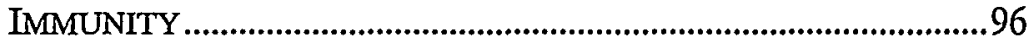

II. QUI TAM ACTIONS UNDER THE FALSE CLAIMS ACT..................98

III. THE WAIVER IN THE CONSTITUTIONAL PLAN FOR SUITS BY THE UNITED STATES...............................................................101

A. Reconstructing the Doctrinal Roots of the United States

Suit Waiver

1. Original Jurisdiction over United States-AgainstState Suits.

2. A Conceptual Distinction Between Private and Governmental Suits

3. Avoiding Intergovernmental Conflict Resolution Through Extralegal Measures.

4. Authorizing United States Enforcement of Mutually Incurred State Obligations.

B. The Central Relevance of the United States' Position as a Real Party in Interest

C. The Irrelevance of Litigation Form for Suits Asserting a Sovereign Interest.

1. The Executive Form and Functionalist Federalism Concerns.

2. A Reconstructionalist Approach to Litigation Form in Suits by the United States

3. Conflicting Methodologies: Originalism Versus Functionalism

D. The United States-as-Plaintiff Waiver and the False

Claims Act's Qui Tam Provisions.

* Professor of Law, University of Michigan Law School. B.A. 1983, UCLA; J.D. 1986, Yale. - Ed. I am grateful to Vicki Jackson and Jim Pfander for providing helpful comments on an earlier draft on very short notice, and to Jeffrey Raven for supportive research assistance. I feel it appropriate to mention that I coauthored an amicus brief in the Vermont litigation discussed herein on behalf of Respondent. 


\section{INTRODUCTION}

The Supreme Court closed this millennium with a virtual celebration of state sovereignty, protecting state authority from the reach of congressional power in several significant ways. In a pair of cases, Seminole Tribe v. Florida ${ }^{1}$ and Alden v. Maine, ${ }^{2}$ the Court held that states enjoy a constitutional immunity from being sued without their consent. In Seminole Tribe, the Court opined that "the background principle of state sovereign immunity embodied in the Eleventh Amendment"3 protects states from unconsented suits in federal court. In Alden, the Court held that this principle is not merely embodied in the Eleventh Amendment but rather is also rooted in "fundamental postulates implicit in the constitutional design,"4 and as such it protects states from unconsented suits in their own state courts as well.

In both cases, the Court reaffirmed some previously articulated limitations on and exceptions to this principle of sovereign immunity. ${ }^{5}$ These exceptions include "waivers in the constitutional plan" - situations in which states consented to certain kinds of suits on a wholesale basis when they joined the Union. One such waiver encompasses suits against a state brought by the United States. ${ }^{6}$ Since the Court has severely curtailed congressional authority to abrogate state sovereign immunity $^{7}$ and has made specific consent to suit more difficult to prove, ${ }^{8}$ the ultimate scope of state sovereign immunity turns in signifi-

1. 517 U.S. 44 (1996).

2. 119 S. Ct. 2240 (1999).

3. Seminole Tribe, 517 U.S. at 72.

4. Alden, 119 S. Ct. at 2254.

5. See id. at 2267-68; Seminole Tribe, 517 U.S. at 71 n.14.

6. See Alden 119 S. Ct. at 2267.

7. The Court has foreclosed Congress's ability to abrogate immunity in federal or state court pursuant to its Article I powers. See Alden, 119 S. Ct. at 2260-66 (holding that Congress lacks Article I power to abrogate immunity in state court); Seminole Tribe, 517 U.S. at 66 (overruling Pennsylvania v. Union Gas Co., 491 U.S. 1 (1989)). While reaffirming Congress's authority to abrogate state sovereign immunity pursuant to Section 5 of the Fourteenth Amendment, see Fitzpatrick v. Bitzer, 427 U.S. 445 (1976), the Court has narrowed the scope of this power as well, see, e.g., College Sav. Bank v. Florida Prepaid Postsecondary Educ. Expense Bd., 119 S. Ct. 2219 (1999) (characterizing Lanham Act's application to states as beyond Congress's Section 5 authority); Florida Prepaid Postsecondary Educ. Expense Bd. v. College Sav. Bank, 119 S. Ct. 2199 (1999) (characterizing Patent Act's application to states as beyond Congress's Section 5 authority); City of Boerne v. Flores, 521 U.S. 507 (1997) (invalidating Religious Freedom Restoration Act's application to states as beyond Congress's Section 5 authority).

8. See, e.g., College Sav. Bank, 119 S. Ct. 2219, 2228 (1999) (overruling the acceptability of a "constructive waiver" embraced earlier in Parden v. Terminal Ry. Co., 377 U.S. 184 (1964)); Pennhurst State Sch. \& Hosp. v. Halderman, 465 U.S. 89, 99 (1984) (holding that state consent to suit must be "unequivocally expressed"). But see Wisconsin Dept. of Corrections v. Schacht, 524 U.S. 381, 393-98 (1998) (Kennedy, J., concurring) (suggesting a state might constructively waive its Eleventh Amendment immunity by voluntarily removing a claim against it from state to federal court). 
cant part on the scope of this "plan waiver" for United States suits. While private victims of state violations of federal law may still frequently protect themselves from further injury by seeking prospective relief in federal or state court, ${ }^{9}$ recovery of compensation or monetary punishment for prior injuries will now largely be relegated to suits brought by the United States. It therefore is particularly important now to consider the potential breadth of this plan waiver.

Since the Court's initial recognition of this United States-asplaintiff waiver (hereafter sometimes denoted US/p) in $1892,{ }^{10}$ it has had little occasion to expound the waiver's justifications or scope. ${ }^{11}$ Cases implicating the waiver thus far have involved easy applications of the underlying principle, meaning suits brought in the name of the United States that purport to vindicate national sovereign or proprietary interests and are initiated and directed by federal officials in the executive branch. Given a relative lack of guidance, lower courts facing somewhat atypical forms of litigation have struggled with discerning the proper contours of the US/p waiver. In particular, courts have struggled with and ultimately split on the question whether a qui tam action $^{12}$ under the False Claims Act, ${ }^{13}$ in which a self-selected private individual purports to sue a state in the name of and on behalf of the United States, qualifies as a suit by the United States for purposes of the immunity waiver. ${ }^{14}$

The Supreme Court is now poised to address this issue in Vermont Agency of Natural Resources $v$. United States ex rel. Stevens, ${ }^{15}$ and thus

9. See Ex parte Young, 209 U.S. 123 (1908) (reaffirmed in Alden, 119 S. Ct. at 2267-68),

10. See United States v. Texas, 143 U.S. 621 (1892).

11. Scholars have likewise paid little attention to the scope of this immunity waiver. One scholar has argued recently that the exception ought to be construed very broadly, such that Congress in essence can authorize damages actions against states by private persons asserting their own legal interests. See Jonathan R. Siegel, The Hidden Source of Congress's Power to Abrogate State Sovereign Immunity, 73 TEXAS L. REv. 539 (1995). I think it quite unlikely that the Court will construe the exception so broadly as essentially to swallow the rule. See, e.g., Union Gas, 491 U.S. at 36 (Scalia, J., concurring in part and dissenting in part) ("If Hans [v. Louisiana, 134 U.S. 1 (1890)] means only that federal-question suits for money damages against the States cannot be brought in federal court unless Congress clearly says so, it means nothing at all.").

12. The phrase "qui tam" is shorthand for "qui tam pro domino rege quam pro si ipso in hac parte sequitur," generally interpreted as "Who sues on behalf of the King as well as for himself." BLACK'S LAW DICTIONARY 1251 (6th ed. 1990).

\section{32 U.S.C. $\$ \$ 3729-3733$ (1994).}

14. Compare, e.g., United States ex rel. Foulds v. Texas Tech Univ., 171 F.3d 279 (5th Cir. 1999) (holding that qui tam suit does not qualify for Eleventh Amendment waiver), and United States ex rel. Long v. SCS Bus. \& Tech. Inst., 173 F.3d 870 (D.C. Cir. 1999) (using strong doubts as to qualification for Eleventh Amendment waiver as reason to exclude states from statutory coverage), with, e.g., United States ex rel. Rodgers v. Arkansas, 154 F.3d 865 (8th Cir. 1998) (holding that qui tam suit qualifies for Eleventh Amendment waiver), and United States ex rel. Milam v. University of Tex. M.D. Anderson Cancer Ctr., 961 F.2d 46 (4th Cir. 1992) (same).

15. 119 S. Ct. 2391 (1999) (granting cert.). The court of appeals held that a qui tam suit 
to explore the contours of the undertheorized US/p immunity waiver. The Court hinted in Alden that the waiver might exclude suits brought on behalf of the United States by private plaintiffs rather than by public officials. This ultimate conclusion, however, rests in tension with the Court's professed commitment, throughout its immunity jurisprudence generally and its waiver jurisprudence specifically, to an originalist methodology; one that focuses on the nature of the legal interest asserted rather than on the structural form of the litigation. This methodology suggests that the Court should ascertain merely whether a particular suit is brought on behalf of the United States to vindicate its sovereign or proprietary interests, and leave it to Congress to select an appropriate, constitutionally acceptable form of litigation through which to assert such interests. ${ }^{16}$

Part I of this Article briefly describes the principle of state sovereign immunity. Part II presents the concept of qui tam litigation and outlines the particular structure of the False Claims Act's enforcement provisions. Part III explores the doctrine of "waivers in the constitutional plan" with respect to litigation by the United States. Here I develop the argument that the central determinant of the waiver's applicability to a given suit is whether the United States is a real party in interest to a dispute with a state. If so, the waiver should trump any erstwhile state sovereign immunity whatever the structural form of the litigation on the United States' behalf, as long as that structural form is otherwise within the power of Congress to employ. Because False Claims Act litigation asserts the United States' own sovereign and proprietary interests, qui tam enforcement of the Act against states is not properly subject to a sovereign immunity defense.

does qualify for the immunity waiver, and also held that the False Claims Act covers states as "persons" who are potentially subject to liability for violating the Act. United States $e x$ rel. Stevens v. Vermont Agency of Natural Resources, 162 F.3d 195 (2d Cir. 1998). The Supreme Court's grant of certiorari encompasses both issues.

16. For purposes of this Article, I shall assume that the qui tam model of litigation on behalf of the United States comports with the Constitution in general, and the only question I explore is whether the model is constitutional as applied to unconsenting state defendants. Despite the venerable tradition of the qui tam model, defendants have argued that qui tam plaintiffs lack standing under Article III; that their representative role runs afoul of the Appointments Clause of Article II; and that the President lacks sufficient oversight capability to exercise his vested executive power. These challenges have thus far met with little success in the lower courts. For an argument (predating some relevant precedent) defending the constitutionality of the False Claim Act's qui tam enforcement scheme, see Evan Caminker, The Constitutionality of Qui Tam Actions, 99 YALE L.J. 341 (1989). But see James T. Blanch, Note, The Constitutionality of the False Claims Act's Qui Tam Provision, 16 HARv. J.L. \& PUB. POL'Y 701 (1993) (arguing that the statute is unconstitutional). 


\section{THE BACKGROUND PRINCIPLE OF STATE SOVEREIGN IMMUNITY}

The textual and historical hook for the constitutional principle of state sovereign immunity is the Eleventh Amendment. ${ }^{17}$ A majority of the Court has long held, however, that this Amendment was intended merely to confirm the Framers' original understanding of this principle in the wake of the Court's erroneous rejection of a sovereign immunity defense in Chisholm v. Georgia." ${ }^{18}$ Because "[ $\left.t\right]$ he Eleventh Amendment confirmed rather than established sovereign immunity as a constitutional principle; it follows that the scope of the States' immunity from suit is demarcated not by the text of the Amendment alone but by fundamental postulates implicit in the constitutional design."19 Thus, the Court has long

"understood the Eleventh Amendment to stand not so much for what it says, but for the presupposition ... which it confirms." That presupposition, first observed over a century ago in Hans v. Louisiana, has two parts: first, that each State is a sovereign entity in our federal system; and second, that "[I]t is inherent in the nature of sovereignty not to be amenable to the suit of an individual without its consent."20

Last Term, the Supreme Court made clear that its long-standing reference to states' Eleventh Amendment immunity is "something of a misnomer." In Alden, the Court held that the states' immunity from suit is a "fundamental aspect of the sovereignty which the States enjoyed before ratification of the Constitution,"22 and an aspect that still "inheres in the system of federalism established by the Constitution."23 As such, states can invoke this immunity defense in their own courts as well as in federal courts. And in neither court may Congress abrogate

17. "The Judicial power of the United States shall not be construed to extend to any suit in law or equity, commenced or prosecuted against one of the United States by Citizens of another State, or by Citizens or Subjects of any Foreign State." U.S. CONST. amend. XI.

18. 2 U.S. (2 Dall.) 419 (1793) (holding Georgia was suable without its consent in the Supreme Court by an out-of-state citizen on an action of assumpsit). There is common agreement that the Eleventh Amendment was intended to overrule Chisholm's holding, though both Seminole Tribe and Alden reflect sharp disagreement among the Justices over whether this overruling was intended to be broad or narrow. For a general discussion of the competing interpretive camps, see ERWIN CHEMERINSKY, FEDERAL JURISDICTION $\$ 7.3$ (2d ed. 1994).

19. Alden v. Maine, 119 S. Ct. 2240, 2254 (1999); see also, e.g., Principality of Monaco v. Mississippi, 292 U.S. 313, 322 (1934) ("Behind the words of the constitutional provisions are postulates which limit and control.").

20. Seminole Tribe v. Florida, 517 U.S. 44, 54 (1998) (quoting Blatchford v. Native Village of Noatak, 501 U.S. 775, 779 (1991) (citations omitted)).

21. Alden, 119 S. Ct. at 2246.

22. Id. at $2246-47$.

23. Id. at 2255 . 
the states' erstwhile immunity through legislation exercising any of its Article I powers. ${ }^{24}$

The immunity principle does not encompass suits against a local governmental entity that does not qualify as an "arm of the State",25 nor certain actions against individual state officers for injunctive or declaratory relief, ${ }^{26}$ nor suits for monetary damages against a state official in her individual capacity "so long as the relief is sought not from the state treasury but from the officer personally."27 One might roughly capture these exclusions by stating that the principle extends to suits in which the state is a "real ... party in interest."28

A state may also waive its immunity by specifically consenting to be sued in state or federal court or both. A state can consent to suit on a case-by-case basis, or it can permit itself to be sued for an entire class of cases. Any variety of consent must be clearly expressed. ${ }^{29}$

In addition, the Supreme Court has long held that the states waived certain aspects of their erstwhile immunity when they joined the Federal Union, either originally or later on "equal footing" with the original states. ${ }^{30}$ Suits brought against a state by the United States ("US/p suits") or a sister state ("state/p suits") are two such waivers. Other categories include certain types of federal constitutional claims brought by individuals, suits brought pursuant to federal statutes properly designed to enforce individuals' Fourteenth Amendment rights, and Supreme Court appellate jurisdiction over all federal claims brought by individuals. ${ }^{31}$

This Article concerns the plan waiver for suits brought against a state by the United States. As the Court has repeatedly reaffirmed, "nothing in [the Eleventh Amendment] or any other provision of the Constitution prevents or has ever been seriously supposed to prevent a State's being sued by the United States."32 This plan waiver has

24. See Alden, 119 S. Ct. at 2248 (no abrogation in state court); Seminole Tribe, 517 U.S. at 47 (no abrogation in federal court).

25. See, e.g., Alden, 119 S. Ct. at 2267; Lincoln County v. Luning, 133 U.S. 529 (1890).

26. See, e.g., Ex parte Young, 209 U.S. 123 (1908).

27. Alden, 119 S. Ct. at 2267-68; see also, e.g., Scheuer v. Rhodes, 416 U.S. 232, 237-38 (1974).

28. Edelman v. Jordan, 415 U.S. 651, 663 (1974) (quoting Ford Motor Co. v. Department of Treasury, 323 U.S. 459, 464 (1945) (internal quotation marks omitted)); see also discussion infra text accompanying notes 101-02.

29. See cases cited supra note 8 .

30. See, e.g., Alden, 119 S. Ct. at 2246-47 (stating that states "retain [their original immunity] today... except as altered by the plan of the Convention or certain constitutional Amendments").

31. See infra notes 76-77 and accompanying text.

32. United States v. Mississippi, 380 U.S. 128, 140 (1965); see also, e.g., Alden, 119 S. Ct. at 2267; Seminole Tribe v. Florida, 517 U.S. $44,71 \mathrm{n} .14$ (1996). 
typically been applied by the Court in what might be called the "exemplar" case, meaning a suit commenced and litigated by a public official in the name of the United States, based on an injury to a cognizable interest of the United States in its sovereign or proprietary capacity, to secure relief inuring to the benefit of the United States or the public at large. Qui tam actions raise the question of whether the plan waiver also encompasses suits that seek to vindicate identical interests of the United States, but are commenced and prosecuted by private individuals rather than by public officials. The next Part describes the unique structure of qui tam litigation in greater detail, highlighting the ways in which it is both similar and dissimilar to the exemplar case.

\section{QUI TAM ACTIONS UNDER THE FALSE ClAIMS ACT}

The "United States" can act only through the agency of persons. A qui tam enforcement scheme is one in which both public officials and private citizens may litigate on behalf of the United States to enforce statutory mandates. In a qui tam action, a private person (often called a "relator" or "informer") maintains a civil proceeding on behalf of both herself and the United States to recover damages, or to enforce penalties available under a statute prohibiting specified conduct, or both. She shares a percentage of any monetary recovery obtained for the United States.

Congress built upon an early American tradition of qui tam enforcement ${ }^{33}$ by incorporating this scheme into the False Claims Act, which imposes civil liability upon persons presenting false claims for payment to or otherwise defrauding the Federal Treasury. ${ }^{34}$ After its original enactment in $1863^{35}$ to "stop[] the massive frauds perpetrated [against the Union Army] by large [defense] contractors during the Civil War," ${ }^{36}$ the Act's qui tam provisions were rarely invoked through much of this century due to "restrictive statutory amendments and judicial interpretations." 37 In 1986, however, Congress reinvigorated the

33. See infra notes 146-51 and accompanying text (describing historical tradition of qui tam litigation on behalf of federal and state governments).

34. See 31 U.S.C. $\$ 3729$ (1994). Specifically, the Act imposes liability on "[a]ny person" who "knowingly presents, or causes to be presented, to an officer or employee of the United States Government ... a false or fraudulent claim for payment or approval" or who "conspires to defraud the Government by getting a false or fraudulent claim allowed or paid." Id. $\$ 3729$ (a)(1), (a)(3). Such a person is "liable to the United States Government for a civil penalty of not less than $\$ 5,000$ and not more than $\$ 10,000$, plus 3 times the amount of damages which the Government sustains." Id. \$ 3729(a).

35. Act of Mar. 2, 1863, ch. 67, 12 Stat. 696.

36. United States v. Bornstein, 423 U.S. 303, 309 (1976).

37. See Caminker, supra note 16 , at 343 \& n.12. 
Act's qui tam framework in an effort to fortify the government's antifraud efforts. ${ }^{38}$

Congress recognized both that detecting fraud is extremely difficult without the aid of informers (because knowledgeable individuals either do not care enough to report it or are associated in some manner with the perpetrators), and that detected fraud frequently is not prosecuted by public officials because of resource constraints. ${ }^{39}$ Qui tam authorization provides the necessary avenue and incentive for knowledgeable individuals to come forward to support and supplement public law enforcement efforts: "[O]ne of the least expensive and most effective means of preventing frauds on the Treasury is to make the perpetrators of them liable to actions by private persons acting, if you please, under the strong stimulus of personal ill will or the hope of gain." 40

The current False Claims Act authorizes the executive branch, namely the Department of Justice (DOJ), to litigate on behalf of the United States. The DOJ may file its own actions, over which it enjoys exclusive and plenary control. ${ }^{41}$ But the Act also provides that "[a] person may bring a civil action for a violation of [the Act] for the person and for the United States Government. The action shall be brought in the name of the Government."42 Thus the Act authorizes private litigants to assert the legal interests of the United States; qui tam suits are brought "for the person" only in the sense that the litigant may earn a reward. ${ }^{43}$ To be sure, the Act specifies that qui tam plaintiffs are parties in their own right, ${ }^{44}$ but the United States is traditionally understood to be the primary party plaintiff in any action "no matter who brings it on its behalf." 45

Under the conventional model of qui tam litigation prevailing at the time of the Founding, if a public prosecutor filed an action first with respect to a given claim, no private role was permitted. And if a private relator filed a qui tam action first, no active public role was permitted. ${ }^{46}$ Even by the mid-1860s, under the original False Claims

38. See id. at 343-44.

39. See id. at $350-51$.

40. Hughes Aircraft Co. v. United States ex rel. Schumer, 520 U.S. 939, 949 (1997) (citations omitted).

41. See 31 U.S.C. $\$ 3730$ (a) (1994).

42. Id. $\$ 3730(\mathrm{~b})(1)$. tion).

43. See infra notes 177-79 and accompanying text (providing more extensive explana-

44. See 31 U.S.C. $\$ 3730$ (c).

45. United States v. B.F. Goodrich, 41 F. Supp. 574, 575 (S.D.N.Y. 1941).

46. See, e.g., United States v. Griswold, 24 F. 361, 364 (D. Or. 1885) (stating that at common law, an action initiated by a qui tam plaintiff remained "exclusively under his control"); Harold J. Krent, Executive Control over Criminal Law Enforcement: Some Lessons 
Act public officials overseeing privately initiated suits were granted only the entirely defensive power to object to a proposed settlement or voluntary cessation of the action by the relator, so as to prevent private collusion from adversely affecting the United States' interests. $^{47}$

By contrast, the modern version of the False Claims Act's qui tam provisions provides public officials with significantly greater affirmative and negative oversight capabilities. ${ }^{48}$ According to the 1986 amendments, when a qui tam plaintiff files an action, the DOJ has sixty days (or more, with court consent) in which to conduct a "diligent[]" investigation of the qui tam plaintiff's allegations and decide whether to enter and direct the litigation." If the DOJ so elects, "it shall have the primary responsibility for prosecuting the action, and shall not be bound by an act of the person bringing the action," though the qui tam plaintiff remains a party and may continue to participate in the litigation. ${ }^{51}$ The DOJ does face procedural or substantive hurdles, however, if it decides to dismiss or settle the case over the qui tam relator's objections. ${ }^{52}$

from History, 38 AM. U. L. REV. 275, 302 (1989) (noting that the government historically had no authority to intervene in a privately initiated qui tam action).

47. See Act of Mar. 2, 1863, ch. 67, § 4, 12 Stat. 696, 698; Griswold, 24 F. at 364.

48. Between 1943 and 1986, the False Claims Act provided the executive branch with an unprecedented degree of oversight authority. During that period, the Act authorized the Department of Justice to intervene and assume exclusive responsibility for litigating qui tam actions; the original private plaintiff could continue the prosecution only if the DOJ declined to enter or if the "United States... fail[ed] to carry on such suit with due diligence...." Act of Dec. 23, 1943, 57 Stat. 608, 609 (current version at 31 U.S.C. $\$ 3730$ ). The complete exclusion of a continuing role for the qui tam relator post-government intervention, combined with a realistic suspicion that the government would displace the relator but then refrain from vigorous prosecution, helped explain why the Act was invoked so infrequently during this period. See supra text accompanying note 37. The 1986 Amendments maintained the government's intervention role but reauthorized some ongoing relator participation in order to mollify this concern. See False Claims Amendments Act of 1986, Pub. L. No. 99-562, § 3, 100 Stat. 3153, 3154-57 (codified as amended at 31 U.S.C. $\$ 3730$ (1994)).

49. See 31 U.S.C. $§ 3730(a),(b)(2)$-(4). To aid the government's investigation, the qui tam plaintiff's complaint is filed under seal and not served on the defendant, and the plaintiff must provide the government with a copy of the complaint and a written disclosure of substantially all material evidence and information in her possession. See id $\$ 3730(b)(2)$.

50. 31 U.S.C. $\$ 3730(c)(1)$.

51. See id. The DOJ may seek a court order restricting the relator's participation upon a showing that unfettered participation would "interfere with or unduly delay the Government's prosecution of the case, or would be repetitious, irrelevant, or for the purposes of harassment." Id. \$3730(c)(2)(C).

52. The qui tam plaintiff is entitled to notice and a hearing prior to dismissal, see 31 U.S.C. \& 3730(c)(2)(A), so as to prevent the DOJ from "drop[ping] the false claims case without legitimate reason." S. REP. NO. 345, at 99-345, reprinted in 1986 U.S.C.C.A.N. 5266, 5291. The DOJ may settle the case over the qui tam plaintiff's objections only if the court determines after a hearing that the settlement is "fair, adequate, and reasonable under all the circumstances." 31 U.S.C. $\$ 3730$ (c)(2)(B). 
Alternatively, the DOJ may leave the primary responsibility for directing the litigation to the qui tam plaintiff and monitor her progress and performance..$^{53}$ The DOJ must consent prior to any dismissal of the action. ${ }^{54}$ And, the DOJ may change its mind and intervene at any later date, upon a showing of good cause, to assume a more significant role in the litigation. ${ }^{55}$ The Act therefore provides the DOJ with substantial control over qui tam litigation, even while it offers strong incentives for private initiative given the relator's share in any recovery. Specifically, a successful plaintiff is generally entitled to share $15 \%$ to $25 \%$ of the recovery if the DOJ intervenes to assume primary responsibility for conducting the litigation, and $25 \%$ to $30 \%$ if the DOJ does not intervene. A $10 \%$ ceiling is imposed if the suit is based upon certain publicly available information.

Because False Claims Act litigation initiated by a qui tam relator differs structurally from the exemplar case commenced and prosecuted solely by an executive branch official, we must explore the theoretical underpinnings of sovereign immunity waiver doctrine to determine that doctrine's applicability.

\section{THE WAIVER IN THE CONSTITUTIONAL PLAN FOR SUITS BY THE UNITED STATES}

In this Part, I first trace the Court's historical exegesis of the US/p waiver doctrine. Of the various explanations the Court has advanced at different times, only two are plausible. These two rationales are then used to buttress the conclusion driven by general immunity doctrine that the waiver's applicability turns on the presence and nature of the United States' own interest, and not on the form of the litigation. Next, I explain why an insistence on a particular structural form of suit is inconsistent with the Court's self-proclaimed originalist methodology. Finally, I demonstrate why allowing qui tam suits against states under the False Claims Act satisfies the historical and conceptual rationales underlying the state immunity waiver for suits by the United States as plaintiff.

\section{A. Reconstructing the Doctrinal Roots of the United States Suit Waiver}

The obvious starting point for discussion is United States v. Texas, ${ }^{56}$

53. See 31 U.S.C. $\$ 3730(c)(3)$.

54. See id. $\$ 3730(\mathrm{~b})(1)$.

55. See id. $\S 3730$ (c)(3). To monitor the litigation prior to an intervention decision, the DOJ may request that it be served with copies of all pleadings filed, and copies of all deposition transcripts. See id.

56. 143 U.S. 621 (1892). 
where the Court first expressly considered and articulated the United States-as-plaintiff waiver. The Attorney General of the United States invoked the Supreme Court's original jurisdiction to sue Texas, seeking to quiet title to land whose ownership, per a series of federal treaties, was disputed. Texas demurred on several grounds, including that "a State cannot be sued without its express consent"; that the federal "judicial power does not extend to controversies between the United States and an individual State"; and even if it does the Supreme Court "is without original jurisdiction in [such] cases." 57

The Court's responses to these challenges are somewhat convoluted and intertwined; indeed, at points the opinion implies that the mere existence of jurisdiction defeats any claim of immunity. It is thus necessary to tease apart the separate strands of the Court's argument, beginning with the issue of original jurisdiction.

\section{Original Jurisdiction over United States-Against-State Suits}

The Court properly recognized that the suit easily fell within the jurisdictional menu of Article III, both because the suit is "one arising under the Constitution, laws and treaties of the United States, and, also, one in which the United States is a party." 58 In explaining why the Court had original rather than merely appellate jurisdiction, the Court advanced the following textual argument:

[The Constitution] extends the judicial power of the United States "to all cases," in law and equity, arising under the Constitution, laws and treaties of the United States, and to controversies in which the United States shall be a party, and confers upon this court original jurisdiction "in all cases" "in which a State shall be party," that is, in all cases mentioned in the preceding clause in which a State may, of right, be made a party defendant, as well as in all cases in which a State may, of right, institute a suit in a court of the United States. The present case is of the former class. $^{59}$

The Court suggests here that its original jurisdiction extends to any Article III case or controversy in which a state is a party, regardless of whether the case owes its place in Article III to the fact of the state's presence as a party or to some other factor (such as subject matter or the presence of the United States as a party). But elsewhere the Court has rejected such an expansive understanding of its original jurisdiction, holding that the jurisdiction encompasses only those cases in which the state's presence as a party is the foundation for Article III jurisdiction. ${ }^{60}$

57. Texas, 143 U.S. at $624,627$.

58. Id. at 643 .

59. Id. at 644; see also id. at 646 (essentially repeating same analysis).

60. Chief Justice Marshall opined this as early as 1821. See Cohens v. Virginia, 19 U.S. 
Perhaps the Court placed greater reliance on a structural analogy than on its strained textual claim. The Court next invoked a comparison of United States-against-state suits and state-against-state suits and asserted that "[i]t would be difficult to suggest any reason why this court should have jurisdiction to determine questions of boundary between two or more States, but not jurisdiction of controversies of like character between the United States and a State."61

But whatever the best support for the Court's holding that United States-against-state suits fall within its original jurisdiction, ${ }^{62}$ this holding by itself does not support the further conclusion that states waived their erstwhile immunity from such suits merely by joining the Union. Even if there were an explicit grant of original jurisdiction for suits between the United States and a state, the grant could still be interpreted against the background principle of immunity, such that jurisdiction would lie only with the defendant's specific consent. To be sure, at times the Court has supported its conclusion that states waived their immunity from suits brought by sister states by noting Article III's express inclusion of "controversies... between two or more states," suggesting that this text "by necessity contemplated jurisdiction over suits to which States were defendants." tion and immunity are discrete concepts, the conclusion does not logically follow, and indeed the Court has rejected this line of reasoning in other contexts. ${ }^{64}$ Thus even assuming Article III encompasses all con-

(6 Wheat.) 264, 393-94, 398 (1821). Just three years after Texas, the Court explained that "[i]f, by virtue of the subject-matter, a case comes within the judicial power of the United States, it does not follow that it comes within the original jurisdiction of this court. That jurisdiction does not obtain simply because the State is a party." California v. Southern Pac. Co., 157 U.S. 229, 261 (1895). See James E. Pfander, Rethinking the Supreme Court's Original Jurisdiction in State-Party Cases, 82 CAL. L. REv. 555, 575 (1994) (observing that this understanding of the Texas Court's textual argument for original jurisdiction "did not take hold").

For an interesting revisionist interpretation of the clause as encompassing state-party suits within Article III jurisdiction because they arise under federal law, see $i d$. (defending this reading as a basis for concluding that the state-party original jurisdiction clause was designed to waive state sovereign immunity in all cases arising under federal law).

61. 143 U.S. at 645. Subsequent Justices have emphasized nontextual justifications for this aspect of the Court's holding in Texas, suggesting that the Court expanded its original jurisdiction to encompass this category of disputes notwithstanding the lack of a clear textual foundation. See, e.g., Ex parte Republic of Peru, 318 U.S. 578, 598 (1943) (Frankfurter, J., dissenting) (supporting the Texas Court's conclusion "although the merely literal language of the Constitution precluded it (as the dissent in that case insisted)").

62. See Pfander, supra note 60, at $575 \mathrm{n} .77$ (noting the presence of "substantial historical support ... for reading the Court's original jurisdiction as encompassing controversies between the United States and a state"); cf., e.g., THE FEDERALIST No. 80, at 476 (Alexander Hamilton) (Clinton Rossiter ed., 1961) ("Controversies between the nation and its members [meaning states] or citizens can only be properly referred to the national tribunals. Any other plan would be contrary to reason, to precedent, and to decorum.").

63. Alden v. Maine, 119 S. Ct. 2240, 2249 (1999).

64. For example, the text of Article III also encompasses suits between "a state ... and foreign States," clearly contemplating that one of the two sovereigns in such suits will be a 
troversies between the United States and a state, the conclusion that the states waived erstwhile sovereign immunity for such disputes remains in need of further justification. Perhaps in recognition of this, the Texas Court provided two additional rationales for this conclusion.

\section{A Conceptual Distinction Between Private and Governmental Suits}

In a subsequent passage the Texas Court invoked a sharp distinction between suits brought by private individuals and suits brought by governmental entities. The Court reaffirmed the proposition that " it is inherent in the nature of sovereignty not to be amenable to the suit of an individual without its consent." "65 The Court continued:

The question as to the suability of one government by another government rests upon wholly different grounds. Texas is not called to the bar of this court at the suit of an individual, but at the suit of the government established for the common and equal benefit of the people of all the States. The submission to judicial solution of controversies arising between these two governments, "each sovereign, with respect to the objects committed to it, and neither sovereign with respect to the objects committed to the other," McCulloch v. State of Maryland, 4 Wheat. 316, 400,410 , but both subject to the supreme law of the land, does no violence to the inherent nature of sovereignty .... The exercise, therefore, by this court, of such original jurisdiction ... in a suit brought by the United States against a State to determine the boundary between a Territory of the United States and that State, so far from infringing, in either case, upon the sovereignty, is with the consent of the State sued. Such consent was given by Texas when admitted to the Union upon an equal footing in all respects with the other States. ${ }^{66}$

This response suggests that the states' sovereign immunity by definition extends only to private and not governmental suits.

This bright-line distinction finds some echoes in early discussions of state sovereign immunity. ${ }^{67}$ Moreover, it superficially conforms to

defendant. And yet despite this analogous contemplation the Court has rejected the contention that either the domestic or foreign state can be sued without its specific consent. See Principality of Monaco v. Mississippi, 292 U.S. 313, 323-24 (1934). Moreover, if one interpreted a hypothesized express jurisdictional grant for suits between the United States and a state necessarily to trump the state's sovereign immunity where it is the defendant, one would expect to arrive by the same reasoning at the conclusion that the grant necessarily trumps the United States' sovereign immunity where it is the defendant, an implication also previously rejected. See, e.g., Kansas v. United States, 204 U.S. 331, 341 (1907).

65. 143 U.S. at 645-46 (quoting Hans v. Louisiana, 134 U.S. 1, 13 (1890)).

66. 143 U.S. at 646.

67. The Court has frequently invoked Alexander Hamilton's sparse comment that "[i]t is inherent in the nature of sovereignty not to be amenable to the suit of an individuai without its consent." THE FEDERALIST, supra note 62, No. 81 (Alexander Hamilton), at 487 (emphasis added); see also Alden, 119 S. Ct. at 2249 (reporting James Madison's statement that "[i]t is not in the power of individuals to call any state into court" (quoting 3 THE DEBATES In tHE SEVERAL STATE CONVENTIONS ON THE FEDERAL CONSTITUTION 533 (Jonathon Elliot ed., Philadelphia, J.B. Lippincott \& Co. 2d ed. 1866) (emphasis added) (in- 
the Court's frequent suggestion that "[t]he principle of sovereign immunity preserved by constitutional design 'thus accords the States the respect owed them as members of the federation." "68 This is not to say that dignitary values are the sole determinants of sovereign immunity jurisprudence; the Court frequently adverts to fiscal concerns as well. ${ }^{69}$ Still, being haled into court by a "mere" individual arguably poses a starker threat to a state's dignity than being haled into court by a coequal or even superior sovereign. ${ }^{70}$

But this dignity-based distinction between individual and sovereign plaintiffs has not withstood the test of time; during the past century the Court has made clear that the background immunity principle covers both categories, and immunity waivers fall into both categories as well. In The Principality of Monaco v. Mississippi ${ }^{71}$ for example, the Court addressed the question of whether a state maintains sovereign immunity from suits by a foreign nation. ${ }^{22}$ The Court said yes, proclaiming broadly that states maintained their immunity from suit without specific consent "save where there has been 'a surrender of this immunity in the plan of the convention." "73 This reasoning implicitly presumes that the default immunity applies to all unconsented suits, not just to suits by private individuals as had sometimes been asserted previously. The Court explicitly reaffirmed this understanding

ternal quotation marks omitted))).

68. Alden, 119 S. Ct. at 2263 (quoting Puerto Rico Aqueduct \& Sewer Auth. v. Metcalf \& Eddy, Inc., 506 U.S. 139, 146 (1993)); see also, e.g., Idaho v. Coeur d'Alene Tribe, 521 U.S. 261, 268 (1997) (recognizing "the dignity and respect afforded a State, which the immunity is designed to protect").

69. See, e.g., Alden, 119 S. Ct. at 2264; Carlos Manuel Vázquez, What Is Eleventh Amendment Immunity?, 106 YALE L.J. 1683, 1714-44 (1997). And many Justices have objected that dignity is not a sensible justification for sovereign immunity. See, e.g., Alden, 119 S. Ct. at 2289 (Souter, J., dissenting) ("Whatever justification there may be for an American government's immunity from private suit, it is not dignity."); Puerto Rico Aqueduct, 506 U.S. at 151 (Stevens, J., dissenting) (describing the dignity foundation for immunity doctrine as "embarrassingly insufficient").

70. See, e.g., Alden, 119 S. Ct. at 2264 ("Private suits against nonconsenting States, however, present 'the indignity of subjecting a State to the coercive process of judicial tribunals at the instance of private parties....'" (emphases added) (citations omitted)).

71. 292 U.S. 313 (1934).

72. Mississippi had issued sets of bonds in 1833 and 1838 . The descendants of the original bond purchasers believed that Mississippi had long ago defaulted on the bonds, but that they could not sue the state because of the Court's expansive interpretation of the Eleventh Amendment in Hans. The bondowners therefore made an unconditional gift of the bonds to the Principality of Monaco, on the assumption that a foreign government could maintain a suit against Mississippi for recovery of the bonds' accrued value without running afoul of state sovereign immunity. This assumption was no doubt bolstered by previous dicta tracking the private/governmental plaintiff distinction. See, e.g., United States v. Minnesota, 270 U.S. 181, 195 (1926) ("Of course the immunity of the State is subject to the constitutional qualification that she may be sued in this Court by the United States, a sister State, or a foreign State." (emphasis added) (citing United States v. Texas, 143 U.S. 621, 642 (1892))).

73. Monaco, 292 U.S. at 322-23 (citing THE FEDERALIST No. 81(Alexander Hamilton)). 
in Blatchford v. Native Village of Noatak, ${ }^{74}$ where the Court rejected the claim that states waived their erstwhile immunity from suit by Indian tribes. The Court conceded that the limitation of sovereign immunity to private suits "finds some support both in the apparent understanding of the Founders and in dicta of our own opinions... [b]ut ... the notion that traditional principles of sovereign immunity only restrict suits by individuals was rejected in" Monaco. ${ }^{75}$

The flip side of the distinction has been rejected as well: the Court has also recognized certain plan waivers for suits by private individuals. For example, the Court has held that states waived their sovereign immunity both from Supreme Court appellate jurisdiction over all suits brought against them by private individuals ${ }^{76}$ and from original jurisdiction in any court over certain types of claims brought against them by private individuals. ${ }^{77}$ Thus, the distinction the Court drew in Texas between suits by individuals and suits by other sovereigns has long been rejected.

\section{Avoiding Intergovernmental Conflict Resolution Through Extralegal Measures}

The Texas Court also provided a rationale for the US/p plan waiver that emphasized the Framers' desire to provide a forum for the peaceful resolution of intersovereign disputes. The Court recognized the "possibility that controversies, capable of judicial solution, might arise between the United States and some of the States,"78 and opined that "the permanence of the Union might be endangered if to some tribunal was not entrusted the power to determine them according to

74. 501 U.S. 775 (1991).

75. Blatchford, 501 U.S. at 780; see also Idaho v. Coeur d'Alene Tribe, 521 U.S. 261, 268 (1997) (interpreting Blatchford as "reject[ing] the contention that sovereign immunity only restricts suits by individuals against sovereigns, not by sovereigns against sovereigns").

76. See McKesson Corp. v. Division of Alcohol Beverages \& Tobacco, 496 U.S. 18, 26 31 (1990).

77. For example, when Congress clearly authorizes private suits against states to enforce Fourteenth Amendment restrictions on state action, states cannot assert an immunity defense. As the Court explained in Alden, "We have held also that in adopting the Fourteenth Amendment, the people required the States to surrender a portion of the sovereignty that had been preserved to them by the original Constitution, so that Congress may authorize private suits against nonconsenting States pursuant to its $\$ 5$ enforcement power. Fitzpatrick v. Bitzer, 427 U.S. 445 (1976)." Alden v. Maine, 119 S. Ct. 2240, 2267 (1999).

See also Reich v. Collins, 513 U.S. 106 (1994) (holding that where a state promises a postdeprivation remedy for taxes collected in violation of federal law, due process requires the state to provide a state judicial forum in which such remedy may be sought); Alden, 119 S. Ct. at 2259 (reaffirming Reich); First English Evangelical Lutheran Church of Glendale v. County of Los Angeles, 482 U.S. 304, 316 n.9 (1987) (suggesting that the Just Compensation Clause constitutes a textual waiver of states' immunity from suits seeking compensation for takings).

78. United States v. Texas, 143 U.S. 621, 644-45 (1892). 
the recognized principles of law." 79 This concern about potential resort to extralegal and bellicose measures echoed some earlier expressions about state suability by sister states. ${ }^{80}$

Subsequently in Monaco, the Court also emphasized this purposive justification for plan waivers, first explaining the waiver for suits by sister-states:

The establishment of a permanent tribunal with adequate authority to determine controversies between the States, in place of an inadequate scheme of arbitration, was essential to the peace of the Union. With respect to such controversies, the States by the adoption of the Constitution, acting "in their highest sovereign capacity, in the convention of the people," waived their exemption from judicial power. ${ }^{81}$

Turning to US/p suits, the Court declared:

Upon a similar basis rests the jurisdiction of this Court of a suit by the United States against a State, albeit without the consent of the latter. While that jurisdiction is not conferred by the Constitution in express words, it is inherent in the constitutional plan. Without such a provision, as this Court said in United States v. Texas, "the permanence of the Union might be endangered." 82

The Court picked up this theme again in Alden, explaining more subtly that the immunity waiver for United States suits was designed to provide a needed "alternative to extralegal measures." 83

This rationale for the US/p plan waiver seems eminently sensible, both as providing a sound conceptualization of state immunity and as providing a plausible motivation for states at the time of the Framing.

79. Id. at 645; see also id. at 641 (reasoning that, absent an available judicial tribunal, "in the end, there must be a trial of physical strength between the government of the Union and Texas": this latter alternative "has no place in our constitutional system, and cannot be contemplated by any patriot except with feelings of deep concern").

80. See, e.g. 3 JOSEPH STORY, COMMENTARIES ON THE CONSTITUTION OF THE UNITED STATES $\$ 1673$, at 543 (1833) (calling federal jurisdiction over two-state disputes "essential to the preservation of the peace of the nation"); Letter from Henry Lee, Governor of Virginia, to the Speaker of the Virginia House of Delegates (Nov. 13, 1793), in 5 THE DOCUMENTARY HISTORY OF THE SUPREME COURT OF THE UNITED STATES, 1789-1800, at 334, 336 (Maeva Marcus et al. eds., 1994) (deprecating state suability by individuals as a "prostitution of State Sovereignty" but admitting that states may have boundary disputes with one another or debts payable to foreign powers, and that such causes "might be productive of Serious quarrels between States, and between States and foreign States"); James E. Pfander, History and State Suability: An "Explanatory" Account of the Eleventh Amendment, 83 CORNELl L. REV. 1269, 1360 (1998) ("In Massachusetts, Virginia, and Georgia, the public debate over Chisholm distinguished sharply between state suability in claims brought by individuals and that in proceedings brought by other governments. Jurisdiction over claims by government plaintiffs was defended on the ground of its necessity to secure peace and harmony; if states lacked the power to sue one another, they might rely upon the sword to settle their disputes.").

81. Principality of Monaco v. Mississippi, 292 U.S. 313, 328-29 (1934) (citations omitted).

82. Id. at 329 (citations omitted).

83. Alden v. Maine, 119 S. Ct. 2240, 2267 (1999). 
At the same time, however, the rationale seems to provide an incomplete explanation for immunity doctrine en toto. The rationale would seem similarly to support an immunity waiver for suits brought against states by foreign states or Indian nations, both independent sovereigns who might well resort to extralegal and hostile measures against states if conflicts could not be mediated in a neutral federal court. Indeed, the Framers were well aware of the real danger to states (as well as to the federal government) posed by foreign and particularly Indian aggression, or state retaliation therefor. ${ }^{84}$ But the Supreme Court refused this seemingly obvious extension of waiver doctrine to suits by foreign nations in Monaco ${ }^{85}$ and by Indian nations in Blatchford ${ }^{86}$ suggesting that the hostility-avoidance rationale is at best not the crux of the story. Indeed, in these latter two cases the Court embraced a slightly different and broader way of portraying the states' original motivation for waiving their immunity from United States and sisterstate suits.

\section{Authorizing United States Enforcement of Mutually Incurred State Obligations}

In Monaco, the Court offered two reasons for refusing to extend the plan waiver to encompass suits by foreign states. The Court first noted that, unlike the waivers previously recognized, this immunity waiver would not be truly "mutual" between the two relevant parties:

The foreign State lies outside the structure of the Union. The waiver or consent, on the part of a State, which inheres in the acceptance of the constitutional plan, runs to the other States who have likewise accepted that plan, and to the United States as the sovereign which the Constitution creates. We perceive no ground upon which it can be said that any waiver or consent by a State of the Union has run in favor of a foreign State. As to suits brought by a foreign State, we think that the States of the Union retain the same immunity that they enjoy with respect to suits by individuals whether citizens of the United States or citizens or subjects of a foreign State. The foreign State enjoys a similar sovereign immunity and without her consent may not be sued by a State of the Union. ${ }^{87}$

84. See, e.g., THE FEDERALIST, supra note 62, No. 3 (John Jay), at 44 ("[T] here are several instances of Indian hostilities having been provoked by the improper conduct of individual States, who are either unable or unwilling to restrain or punish offenses, haveing given occasion to the slaughter of many innocent inhabitants."); Robert N. Clinton, The Dormant Indian Commerce Clause, 27 CONN. L. REv. 1055, 1124-64 (1995) (discussing the effects, inter alia, of actual and threatened armed conflicts between Indian tribes and states in the 1780 s on constitutional framing and discourse).

85. See Monaco, 292 U.S. at 313.

86. See Blatchford v. Indian Village of Noatak, 501 U.S. 775 (1991).

87. 292 U.S. at 330. 
In Blatchford, the Court offered much the same analysis to refuse recognition of a plan waiver for suits brought against states by Indian tribes:

Respondents argue that Indian tribes are more like States than foreign sovereigns. That is true in some respects: They are, for example, domestic. The relevant difference between States and foreign sovereigns, however, is not domesticity, but the role of each in the convention within which the surrender of immunity was for the former, but not the latter, implicit. What makes the States' surrender of immunity from suits by sisters States plausible is the mutuality of the concession. There is no such mutuality with either foreign sovereigns or Indian tribes. We have repeatedly held that Indian tribes enjoy immunity against suits by States, as it would be absurd to suggest that the tribes surrendered immunity in a convention to which they were not even parties. But if the convention could not surrender the tribes' immunity for the benefit of the States, we do not believe that it surrendered the States' immunity for the benefit of the tribes. ${ }^{88}$

The reasoning in both Monaco and Blatchford thus envisions anthropomorphized states sitting around a bargaining table and agreeing to a mutual pact waiving their immunity for certain kinds of suits but not for others. As the Court reconstructs this bargain, states agreed to waive their immunity only where doing so would mutually benefit the parties to the agreement - meaning the states and the United States - and not where it would altruistically benefit outsiders. ${ }^{89}$

88. 501 U.S. at 782 (citation omitted).

89. Monaco also offered a second reason for rejecting the assertion of waiver. "Controversies between a State and a foreign State may involve international questions in relation to which the United States has a sovereign prerogative." 292 U.S. at 331. State defendants may not unilaterally be empowered to exercise a "prerogative of adjustment" in the face of suit by a foreign state; rather,

[t] he National Government, by virtue of its control of our foreign relations is entitled to employ the resources of diplomatic negotiations and to effect such an international settlement as may be found to be appropriate, through treaty, agreement of arbitration, or otherwise. It cannot be supposed that it was the intention that a controversy growing out of the action of a State, which involves a matter of national concern and which is said to affect injuriously the interests of a foreign State, or a dispute arising from conflicting claims of a State of the Union and a foreign State as to territorial boundaries, should be taken out of the sphere of international negotiations and adjustment through a resort by the foreign State to a suit under the provisions of $\$ 2$ of Article III.

Id. at 331-32.

This argument may be persuasive so far as it goes, but the question arises why it does not go farther. First, if it is truly critical that the President's role as international arbiter be protected, why should a state be able to circumvent this role by voluntarily consenting to suit by a foreign nation? Waivability is arguably consistent with immunity doctrine to the extent it is designed to secure the state's sovereign prerogatives; but waivability seems inconsistent with this particular application of immunity designed to preserve presidential rather than state prerogatives. Second, why doesn't this rationale undercut the plan waiver for suits by sister-states? Surely the President has an equally obvious role to play in arbitrating at least the subset of state-against-state disputes that implicate national concerns (perhaps including boundary disputes).

In light of these questions, it is interesting that when the Court later considered state suability by Indian tribes in Blatchford, the Court invoked Monaco's mutuality rationale but 
This rationale provides a justification for the US $/ p$ and state/p plan waivers already recognized. In joining the Union, each state took upon itself a reciprocal set of obligations running to its sister states, some affirmative (for instance, aiding extraditions) and some negative (for instance, eschewing import duties). Each state also took upon itself a set of obligations running to the new national government empowered to supplement or sometimes supplant state authority, again some affirmative (for instance, holding elections for national office) and some negative (for instance, no obstructing federal instrumentalities); these obligations running to the national government were designed in large part for the mutual benefit of the states..$^{90}$ Finally, each state took upon itself a set of obligations running personally to its own citizens (for instance, no bills of attainder) and to noncitizens (for instance, no unjustifiable discrimination against visiting out-of-staters).

Following the Court's premise of a negotiated waiver pact among states, one can imagine the states agreeing to judicial resolution of disputes arising out of the various intersovereign obligations. Each state, let's say Virginia, would have had a strong self-interest in establishing some way of enforcing the obligations its sister states owed to it. To this end, Virginia would have insisted upon the right to sue its neighbors, waiving its own immunity from suit by those same neighbors in a "mutual concession" designed to promote the benefit of all.

In addition, Virginia would have had a strong self-interest in authorizing the United States to sue fellow states, for two reasons. First, the United States could help police the obligations owed to Virginia by its neighboring states. Virginia's right to sue its neighbors, standing alone, might lead to an underenforcement of state-to-state obligations due to collective action problems; each of several injured states might hope to free-ride on the costly enforcement efforts of others. Second, Virginia would want the United States to be able to sue its fellow states to enforce their new commitments made directly to the national government, and to prevent their interference with that government's own interests and institutions that, after all, purported to benefit the country as a whole. To these ends, Virginia would have granted the United States the authority to sue its fellow states, and concomitantly waived its own immunity from suit by the United States in a mutual covenant with its neighbors.

failed to mention its presidential diplomacy rationale even though the latter would seem equally applicable to tribe-against-state disputes.

90. The Constitutional Convention was occasioned primarily by the recognition that the Congress created by the Articles of Confederation lacked sufficient power to enforce the several states' mutual obligations, such as to provide requisitioned troops and funds. See, e.g., Saikrishna Bangalore Prakash, Field Office Federalism, 79 VA. L. REV. 1957, 1963-66 (1993); see also Alden v. Maine, 119 S. Ct. 2240, 2247 (1999) ("Experience under the Articles [of Confederation] had 'exploded on all hands' the 'practicality of making laws, with coercive sanctions, for the States as political bodies.' " (citations omitted)). 
By contrast, consider the obligations owed by Virginia solely to private individuals rather than to the other governments. By waiving its immunity from suit to vindicate the personal interests of individuals, Virginia would put its own treasury at risk, and yet it would not obtain a significant compensatory benefit from the other states' like waiver.

Thus, this line of argument concludes, self-interested states would have mutually agreed to waive their immunity from suits seeking to vindicate the sovereign or proprietary interests of their sister states and "the United States as the sovereign which the Constitution creates,"91 but not the interests of private individuals or foreign nations or Indian tribes, none of whom were participants in the waiver pact. In comparison with the earlier Texas "hostility-avoidance" explanation, this "mutuality" justification for the US/p waiver is driven less by the threat of extralegal and potentially violent measures and more by the promise of beneficial intersovereign cooperation. Moreover, the mutuality rationale supports a waiver that is broader than that suggested by the hostility-avoidance rationale alone. Of course, Virginia would want to authorize the United States to sue where the federal government would otherwise take hostile action toward a state. But Virginia would also want to authorize the United States to sue where it would otherwise remain inert because the costs of extralegal measures are too high, thus failing to assert its sovereign and proprietary prerogatives to the detriment of all of the states (save the one thwarting federal interests at the particular moment)..$^{22}$

\section{Monaco, 292 U.S. at 330.}

92. Given the premise of anthropomorphic state negotiations underlying the mutuality discussion in Monaco and Blatchford, this argument seems plausible. It is noteworthy, however, that the premise itself rests in some tension with the Court's discourse on state sovereignty and federal supremacy in cases as old as McCulloch v. Maryland, 17 U.S. (4 Wheat.) 316 (1819), and as recent as U.S. Term Limits, Inc. v. Thornton, 514 U.S. 779 (1995). In both cases the Court explained that " " $t]$ he government of the Union, then, ... is, emphatically, and truly, a government of the people. In form and in substance it emanates from them,'” Thornton, 514 U.S. at 821 (quoting $M c C$ Culloch, 17 U.S. (4 Wheat.) at 404-05 (alteration in original)); and in both cases the Court rejected the more state-centered proposition that the Constitution "emanat[ed] from the people, but as the act of sovereign and independent States," McCulloch, 17 U.S. (4 Wheat.) at 402; see also Thornton, 514 U.S. at 846 (Thomas, J., dissenting). It thus seems odd for the Court to talk as if it is trying to reconstruct what the states would rationally have agreed to waive in the plan of the convention, as opposed to asking how the people would have wanted to grant and withhold various aspects of governmental sovereignty from both their state and federal governments. (For a rare exception, see Alden, 119 S. Ct. at 2267 (maintaining that "the people required the States to surrender a portion" of their sovereignty).) A more people-oriented perspective would not necessarily lead the Court to divine a different constructive agreement, but it would seem to place a somewhat higher relative value on federal supremacy and the rule of law than these concepts currently appear to enjoy. 
Let me pause here for some methodological observations. On the surface, these latter two explanations - a desire to forestall resort to extralegal measures and a pact to ensure enforcement of mutually beneficial intersovereign obligations - might seem functionalist in nature, because they reflect pragmatic as well as conceptual concerns. However, the Court has grounded these explanations in a selfavowedly originalist approach to constitutional interpretation. In each of the cases previously discussed, the Court repeatedly professes to be discerning and implementing the Framers' original understanding of immunity waivers in the constitutional plan, rather than invoking contemporary notions of the values served and disserved by immunity in different contexts. This originalist approach is entirely consistent with the Court's protection of state immunity in the first place; the seminal cases of Hans, Seminole Tribe, and Alden all purport to reconstruct the Framers' original understanding of the immunity enjoyed and then retained by states during the Founding generation..$^{93}$ And other waiver cases such as Fitzpatrick v. Bitzer ${ }^{94}$ and McKesson Corp. v. Division of Alcohol Beverages \& Tobacco,$^{95}$ similarly focus on the Framers' original views. While one might challenge the Court over the persuasiveness of its originalist claims, one cannot mistake the Court's originalist methodology. ${ }^{96}$

To be sure, the Court has not relied on traditional indicia of an actual historical intent such as constitutional text or the Framers' discussions during the framing or ratification periods. ${ }^{97}$ Instead, the Court has envisioned a hypothetical negotiation during the Framing among

93. For example, see Alden, 119 S. Ct. at 2247-54 (basic immunity); id. at 2256-57 (focusing on view of "founding generation" concerning defeasibility of state immunity by federal statute); and id. at 2260-62 (looking "first to evidence of the original understanding" concerning Congress's authority to abrogate a state's immunity from suit in its own courts). See also id. at 2253-54 (describing Hans, Monaco, and Seminole Tribe as having been grounded in the original understanding of sovereign immunity).

94. 427 U.S. 445 (1976) (focusing on original understanding of Framers of Fourteenth Amendment); see also Alden, $119 \mathrm{~S}$. Ct. at 2267 ("[I]n adopting the Fourteenth Amendment, the people required the states to surrender a portion of the sovereignty that had been preserved to them by the original Constitution....").

95. 496 U.S. 18 (1990) (relying on long-standing judicial practice to confirm original understanding of Founding generation concerning state consent to Supreme Court appellate review of suits against states entertained by state courts).

96. I do not intend in this Article to defend the Court's originalist methodology, either in general or as applied to this particular set of constitutional questions. It suffices for my purposes to note that the Court has consistently employed this interpretative methodology when resolving immunity claims.

97. This is unsurprising given the lack of attention devoted to the issue of immunity waivers of any type. For some snippets of commentary concerning the prospect of United States-against-state or state-against-state suits, none of which are relied upon by the Court in Texas or Monaco, see supra note 80. 
the United States and several states, and invoked both conceptual and pragmatic concerns to discern the most plausible combination of sovereign immunity retention and waiver given the background principles, historical conditions, and purposes of union. This approach to discerning the Framers' original understanding might aptly be characterized as "reconstructionalist" in nature, since it essentially reconstructs the most plausible agreement rather than interprets conventional historical indicia thereof.

\section{B. The Central Relevance of the United States' Position as a Real Party in Interest}

While the "mutuality" rationale provides a more complete justification for the US/p waiver than does the "hostility-avoidance" rationale, the two can be viewed as complementary, and both suggest that the dispositive factor in triggering the waiver is the United States' interest in the dispute with a state. The rationales embrace a common theme: the several states recognized from the beginning that the new national government would have its own set of governmental interests and obligations, and sometimes the United States' interests would be opposed to those of a state. According to the hostility-avoidance rationale, a judicial forum should be available to forestall the United States' resort to extralegal measures, which might otherwise occur whenever a state thwarts some governmental interest of the United States. According to the mutuality rationale, a judicial forum should be available whenever the United States seeks to assert one of the legal prerogatives or interests bestowed upon it in the constitutional design. The relevant question for determining whether the waiver encompasses a particular suit, therefore, is whether the United States' interests are truly at stake in a suit against a state. Thus, the presence of a sufficient sovereign or proprietary interest of the United States in litigation brought on its behalf is a sufficient condition for invoking the US/p waiver.

This conclusion dovetails with other aspects of sovereign immunity doctrine whose application equally turns on the presence and nature of a government's interest in the litigation. With respect to the interests of governmental plaintiffs, the Court has held that a suit brought by a state against a sister state qualifies for the state/p plan waiver only if the plaintiff state is a real party in interest. ${ }^{98}$ In an analogous context, the Court has employed a real-party-in-interest analysis in discerning whether a state plaintiff may avail itself of the Court's original jurisdiction; the presence of a state as a nominal party does not qualify ${ }^{99}$ The original jurisdiction and immunity waiver contexts appear

98. I discuss this case law at infra notes 105-112 and accompanying text.

99. See, e.g., Oklahoma ex rel. Johnson v. Cook, 304 U.S. 387, 393 (1938) ("[I]n deter- 
analogous because both inquiries reflect the states' dignitary interests. ${ }^{100}$ And with respect to governmental defendants, the Court has held that a suit qualifies as one "against the state," thus implicating the state's immunity defense, whenever the state is the real defendant in interest. As the Court has emphasized many times,

$[T]$ he nature of a suit as one against the state is to be determined by the essential nature and effect of the proceeding. And when the action is in essence one for the recovery of money from the state, the state is the real, substantial party in interest and is entitled to invoke its sovereign immunity from suit even though individual officials are nominal defendants. ${ }^{101}$

In other words, one might say that a state counts as the defendant for purposes of sovereign immunity when it is the real party in interest, even if it is "represented" in the litigation (by dint of the plaintiff's pleading) by a state official or entity. ${ }^{102}$

Of course, whether the United States or a state is a real plaintiff in interest in a given lawsuit turns on a prior question: what kind of interest must the government assert to qualify for that appellation? Governments may loosely be said to be "interested" in the outcome of litigation in various ways, and perhaps not all types of interests ought to suffice to trigger a plan waiver of a defendant state's immunity. Indeed, one can imagine a range of answers to this question.

At its very narrowest, the scope of the waiver for United States suits emerging from the states' mutual concessions in the plan of the convention surely would have included both suits brought to vindicate the United States' core proprietary interests (such as the security of its fisc and the maintenance of its territorial boundaries) and suits brought to prevent one state from imposing a harmful externality on its neighbors. ${ }^{103} \mathrm{~A}$ broader conception would include suits brought to

mining the scope of our original jurisdiction... we must look beyond the mere title of the complaining State to the cause of action asserted and to the nature of the State's interest."); id. at 396 ("[T] he State must show a direct interest of its own and not merely seek recovery for the benefit of individuals who are the real parties in interest."); see also CHEMERINSKY, supra note $18, \S 10.3$, at 582 ("Nor may a state invoke the Supreme Court's original jurisdiction where it is not the real party in interest, but instead is suing on behalf of particular citizens who have been injured.").

100. See, e.g., United States v. Texas, 143 U.S. 621, 643 (1892) (stating that original jurisdiction over state-party cases "best comport[s] with the dignity of a State"); Ames v. Kansas ex rel. Johnston, 111 U.S. 449, 464 (1884) (same); see also Cook, 304 U.S. at 392-93 (drawing on Eleventh Amendment case law in applying the real-party-in-interest test for original jurisdiction purposes).

101. Ford Motor Co. v. Department of Treasury, 323 U.S. 459, 464 (1945) (citations omitted); see also, e.g., Regents of the Univ. of Cal. v. Doe, 519 U.S. 425, 429 (1997); Edelman v. Jordan, 415 U.S. 651, 663 (1974).

102. The Court has previously made clear that the same real-party-in-interest inquiry applied to suits involving states also "must apply to the United States." Minnesota v. Hitchcock, 185 U.S. 373, 387 (1902).

103. See supra text accompanying notes $89-90$. 
assert more diffuse and less tangible interests of the United States, perhaps including all situations in which the interests of the nation clash with the interests of a state. The broadest possible conception would include suits brought against states by the United States, not to vindicate its own interests per se, but rather to advance the personal interests of its citizens. Unless this latter conception was endorsed, then the US/p plan waiver would not encompass every action brought on behalf of the United States, by either an executive branch official or a private relator.

The Court has already rejected this broadest possible conception of the waiver pact with respect to state-against-state controversies. In this context, the Court has essentially distinguished between two types of such suits. In "governmental interest" suits the plaintiff state is interested in the litigation for its own sake, meaning it is asserting its own sovereign or proprietary interests. In "nominal interest" suits the plaintiff state asserts no sovereign or proprietary interests, but rather merely asserts the interests of one or more private citizens on their behalf. ${ }^{104}$ In a series of cases the Court has held that when the plaintiff state merely lends its name to vindicate essentially personal interests of some of its citizens, such a "nominal interest" suit fails to qualify for the state/p waiver even when formally litigated by the plaintiff state's executive branch.

In New Hampshire v. Louisiana ${ }^{105}$ for example, the Court upheld Louisiana's claim of immunity against suits commenced by state attorneys general. A number of New Hampshire and New York citizens owned Louisiana bonds and coupons, but could not themselves sue Louisiana in debt actions because of the Eleventh Amendment. By statute, both New Hampshire and New York allowed their citizens to assign the claims to them, such that the states could sue Louisiana on their citizens' behalf without (they hoped) being constrained by state sovereign immunity. Once valid claims were assigned, the states' attorneys general were obligated to bring suit in the name of the state in order to enforce collection, but certain features of the statutes (in-

104. In the context of developing the doctrine of parens patriae standing authorizing states to bring suit in federal court, the Court has described three types of governmental interests: (1) sovereign interests, which include both "the exercise of sovereign power over individuals and entities within the relevant jurisdiction" and "the demand for recognition from other sovereigns" (most frequently through the "maintenance and recognition of borders"); (2) proprietary interests, including conventional "private" interests in owning and managing resources and business ventures; and (3) quasi-sovereign interests, including a vague "set of interests that the State has in the well-being of its populace." See Alfred L. Snapp \& Son, Inc. v. Puerto Rico ex rel. Barez, 458 U.S. 592, 601-02 (1982). The Court has contrasted such governmental interest suits with those in which the state "may, for a variety of reasons, attempt to pursue the interests of a private party, and pursue those interests only for the sake of the [private] real party in interest .... In such situations the State is no more than a nominal party." Id. at 602 .

105. 108 U.S. 76 (1883). 
cluding requiring the individual bondowners to fund the litigation and, in some contexts, allowing them to participate) led the Court to conclude that "both the State and the attorney-general are only nominal actors in the proceeding." 106 The Court melded justiciability and immunity concepts and reasoned in these circumstances that the state plaintiffs lacked a sufficient interest to override the Eleventh Amendment:

The evident purpose of the [Eleventh] amendment ... was to prohibit all suits against a State by or for citizens of other States, or aliens, without the consent of the State to be sued, and, in our opinion, one State cannot create a controversy with another State, within the meaning of that term as used in the judicial clauses of the Constitution, by assuming the prosecution of debts owing by the other State to its citizens. Such being the case we are satisfied that we are prohibited, both by the letter and the spirit of the Constitution, from entertaining these suits .... 107

Contrast this holding with South Dakota v. North Carolina, ${ }^{108}$ where the Court allowed South Dakota to invoke the state/p plan waiver and sue North Carolina to recover for defaulted bonds originally owned by South Dakotans. The difference, the Court explained, was that the individuals gifted, rather than assigned, the bonds to their state such that South Dakota owned them outright rather than held them "as representative of individual owners."109 As such, South Dakota's suit was not encompassed by the Eleventh Amendment. ${ }^{110}$ Viewed together, these cases illustrate the proposition that "[a]n action brought by one state against another violates the Eleventh Amendment if the plaintiff state is actually suing to recover for injuries to designated individuals."111 Determining when a particular action vindicates too little state and too much individual interest may require somewhat subjective line drawing, but the conceptual idea is clear enough. To qualify for the state/p plan waiver, the plaintiff state must be a real party in interest in its own right, meaning it must assert at least a sovereign, proprietary, or quasi-sovereign interest. ${ }^{112}$

106. New Hampshire, 108 U.S. at 89.

107. Id. at 91 (emphasis added); see also Oklahoma ex rel. Johnson v. Cook, 304 U.S. 387, 392-33 (1938) (describing these cases) ("The fact that the effort was made to use the name of the complainant States in order to evade the application of the Eleventh Amendment was undoubtedly a controlling consideration, but that consideration derived its force from the fact that the State was not seeking a recovery in its own interest, as distinguished from the rights and interests of the individuals who were the real beneficiaries.").

108. 192 U.S. 286 (1904).

109. See South Dakota, 192 U.S. at 310.

110. See id. at 315-318.

111. Hawaii v. Standard Oil Co., 405 U.S. 251, 259 n.12 (1972).

112. As mentioned earlier, see cases cited supra notes 99-100 and accompanying text, the Court has drawn a similar, if indeed not the same, line when determining the reach of the Court's original jurisdiction over state-party cases. See, e.g., Cook, 304 U.S. at 396 (stating 
It is an intriguing question whether this outer limit on the scope of the state/p waiver applies as well to the US/p waiver. Professor Jonathan Siegel maintains that the answer is no, because even when the United States purports to vindicate personal interests on the behalf of citizens, it also asserts its own regulatory interest in controlling state behavior, and this regulatory interest is sufficient to qualify for the waiver. ${ }^{13}$ Siegel argues as follows: Given territorial boundaries on the reach of a state's legislative jurisdiction, the state (say New Hampshire) lacks a regulatory interest in making a sister state (say Louisiana) pay its debts to individuals. Thus, New Hampshire can claim no more than to be representing the personal interests of individual citizens. By contrast, the United States-as-plaintiff can claim more; it is not only acting on behalf of individual citizens, but also asserting a regulatory interest in enforcing valid federal laws throughout its jurisdiction, including within any given state. ${ }^{114}$

It follows, claims Siegel, that the "United States is generally a proper party to bring suit to enforce federal law, and this remains true when the defendant is a state."115 As support, he notes that the Court has suggested in passing that the Secretary of Labor may enforce the Fair Labor Standards Act (FLSA) ${ }^{116}$ by suing states on behalf of individual state employees to recover wrongly withheld compensation for them. ${ }^{117}$ This suggests the Court's willingness to assume that the United States' general regulatory interest in enforcing the FLSA suffices to trigger the US/p plan waiver.

that to invoke the Court's original jurisdiction, "the State must show a direct interest of its own and not merely seek recovery for the benefit of individuals who are the real parties in interest").

113. See Siegel, supra note 11, at 554.

114. Such enforcement actions by the United States would seem to fall within the category of sovereign interests, which includes "the power to create and enforce a legal code, both civil and criminal." Alfred L. Snapp \& Son, Inc. v. Puerto Rico ex rel. Barez, 458 U.S. 592,601 (1982).

115. Siegel, supra note 11 , at 554 .

116. 29 U.S.C.A. \$§ 201-219 (West 1998 \& Supp. 1999).

117. In Employees of the Department of Public Health \& Welfare v. Department of Public Health \& Welfare., 411 U.S. 279 (1973), the Court concluded that the Eleventh Amendment barred individual employees from suing a state to recover wrongfully withheld wages, but then noted that the Secretary was authorized to sue offending employers (including states) both to enjoin future violations and to recover restitution for mistreated employees. See id. at 285-86. More recently in Alden, the Court chided the Solicitor General for touting the importance of FLSA enforcement when the United States did not "send] even a single attorney to Maine to prosecute this litigation," Alden v. Maine, 119 S. Ct. 2240, 2269 (1999), implying the latter would have been permissible.

For two other examples of congressional authorization of federal officials to sue to recover damages on behalf of private victims, see Title VII of the Civil Rights Act of $1964 \S$ 706, 42 U.S.C. 2000e-5(f)(1) (1994) (authorizing EEOC to sue for backpay on behalf of victims of employment discrimination); Uniformed Services Employment and Reemployment Rights Act $\$ 2(a), 38$ U.S.C. $\$ 4323$ (a) (1994) (authorizing Attorney General to sue on behalf of aggrieved employees). 
Siegel actually goes much further and argues that the waiver should extend to encompass all federal statutory private rights of action, on the ground that all such suits indirectly serve this federal regulatory interest as well. ${ }^{118}$ The Court, of course, resoundingly rejected this conclusion in Seminole Tribe and Alden. But this rejection does not necessarily deny the possibility that, when properly asserted by the United States, its intangible federal regulatory interest is sufficient to qualify for the US/p waiver even if the only tangible benefits from suit redound to individual citizens. One might reconcile Seminole Tribe and Alden with the Court's dicta in FLSA cases as follows: the intangible regulatory interest "belongs" to the United States, and thus a suit qualifies for the plan waiver only if it is brought by someone congressionally authorized to assert this interest on the United States' behalf in litigation - for instance, an executive branch official or a qui tam plaintiff authorized to sue for and in the name of the United States. ${ }^{119}$ In neither Seminole Tribe nor Alden were the individual plaintiffs authorized to represent the United States' interests, nor did they purport to do so. ${ }^{120}$

One might also reconcile Seminole Tribe and Alden with the Court's dicta in FLSA cases in a slightly different way. A suit that seeks monetary compensation for an individual's personal injury may incidentally also serve other intangible federal interests underlying Congress's statutory scheme, such as deterring future state misconduct and creating favorable precedent regarding the statute's proper interpretation. When the injured party brings suit herself, a court cannot know for sure whether such intangible interests are truly at stake. But when an executive branch official brings suit on the individual's behalf, the official's involvement signals the United States' view that such other national interests will be served, and hence the suit vindicates a sovereign rather than an exclusively private interest.

Alternatively, one might instead question the Court's previous intimation that the US/p waiver would extend to FLSA suits brought by the Secretary of Labor, where the only tangible injury is suffered by the individual victims of state wrongdoing. Perhaps, upon further reflection, the Court would conclude that the states' immunity from "nominal interest" suits brought by sister states should extend to analogous suits brought by the United States as well, the unique presence of an intangible regulatory interest or other intangible interests notwithstanding.

For present purposes I need not definitively resolve the question

118. See Siegel, supra note 11 , at 564-69.

119. E.g., False Claims Act, 31 U.S.C. $\$ 3730(b)(1)$ (1994).

120. Cf. Dunlop v. New Jersey, 522 F.2d 504, 513-17 (3d Cir. 1975) (applying the US/p waiver to Secretary suits following a variant of this line of reasoning), judgment vacated on other grounds sub nom. New Jersey v. Usery, 427 U.S. 909 (1976). 
whether certain suits brought in the name of the United States against a state might still fail to qualify for the US/p plan waiver, even if the prosecution is initiated and controlled by an executive branch official, due to the insufficiently sovereign or proprietary nature of the asserted national interest. As explained earlier, ${ }^{121}$ at its very narrowest the scope of the waiver for United States suits would have included suits brought to vindicate the United States' core proprietary interests and suits brought to prevent one state from imposing a harmful externality on its neighbors. As I will show later, qui tam suits under the False Claims Act easily fall into both categories. ${ }^{122}$

The important conceptual point here is that the US/p waiver is interest-driven. Both the asserted purposes underlying waiver doctrine and the Court's general approach to immunity doctrine ordain that the waiver's applicability should turn on the nature of the United States' interest at stake in litigation brought on its behalf.

\section{The Irrelevance of Litigation Form for Suits Asserting a Sovereign Interest}

Notwithstanding this conclusion, some lower courts have focused on the question whether the form of the litigation matters - for instance, whether the structure of the litigation itself rather than the interest being asserted plays a dispositive role in determining the waiver's scope. ${ }^{123}$ Recently the Supreme Court has hinted at such a view itself. In Blatchford, the Court observed in passing that "[t]he consent, 'inherent in the convention,' to suit by the United States - at the instance and under the control of responsible federal officers - is not consent to suit by anyone whom the United States might select ...."124 And last Term in Alden the Court commented that:

A suit which is commenced and prosecuted against a State in the name of the United States by those who are entrusted to "take Care that the Laws be faithfully executed,"... differs in kind from the suit of an individual .... Suits brought by the United States itself require the exercise of political responsibility for each suit prosecuted against a State, a control which is absent from a broad delegation to private persons to sue nonconsenting States. ${ }^{125}$

121. See supra text accompanying note 103.

122. See infra text accompanying note 174. Indeed, this is so even if one views Congress's power to authorize qui tam suits against states as narrower than its power to authorize public official suits against states. See infra notes 175-176 and accompanying and following text.

123. See, e.g., cases cited supra note 14.

124. Blatchford v. Native Village of Noatak, 501 U.S. 775, 785 (1991).

125. Alden v. Maine, 119 S. Ct. 2240, 2267 (1999) (citation omitted). 
These dicta ${ }^{126}$ suggest that the US/p plan waiver encompasses suits by the United States only if their litigation structure entails initiation and prosecution by an executive branch official. I will call this the "executive form" as opposed to private form of litigation on behalf of the United States.

In neither Blatchford nor Alden, however, did the Court purport to justify its dicta equating suits by the United States and suits by federal officers. If the Court remains committed to its originalist (or "reconstructionalist") methodology, the proposed equation proves difficult to maintain. On its own terms, the equation raises some troubling normative and empirical questions. More significantly, however, the argument's terms are simply inconsistent with the reconstructionalist approach to plan waiver doctrine.

\section{The Executive Form and Functionalist Federalism Concerns}

Alden's language suggests the Court has in mind a functionalist concern: limiting immunity-free suits to those commenced and prosecuted by an executive official would provide states with an additional procedural safeguard protecting their sovereign interests. A state would be immune from suit unless both Congress has determined generally that states ought to be suable for this particular category of misconduct, and the executive branch has determined specifically that a given state ought to be sued for its particular misconduct. A suit would thus require approval by two distinct entities "exercis[ing] ... political responsibility,"127 rather than by just one (Congress) plus an unaccountable private plaintiff.

While intuitively appealing, this "political safeguards of federalism" approach turns out on further reflection to rest on some questionable normative and speculative empirical foundations. To begin with, we can immediately identify and set aside one normatively unappealing argument: an executive form requirement cannot persuasively be justified merely because it would likely lead to fewer suits being filed against states. ${ }^{128}$

126. The Court's passing statement in Blatchford is dictum because the Court held that Congress had not intended to delegate the United States' exemption from state sovereign immunity from the plaintiff Indian tribes. See Blatchford, 501 U.S. at 785-86. In the passage quoted from Alden (and a couple of similar ones), the Court was illustrating a distinction between conventional private suits to enforce private rights under the Fair Labor Standards Act and conventional government-initiated suits brought by the Secretary of Labor. There was no argument that the private plaintiffs were asserting any sovereign legal interests, indeed, any interests other than their own personal ones; and thus there was no occasion for the Court to consider the relevance, if any, of the form of litigation brought on behalf of the United States.

\section{Alden, 119 S. Ct. at 2267.}

128. Executive officials and qui tam relators face different incentives and disincentives to sue perceived wrongdoers. There might be some suits that only a private relator but not 
The Court did note in Alden that suits against states may interfere with their "ability to govern in accordance with the will of their citizens." 129 But this is a byproduct of federal supremacy, and the Court emphatically reaffirmed that " $\mathrm{t}]$ he States and their officers are bound by obligations imposed by the Constitution and by federal statutes that comport with the constitutional design."130 The Court also noted that damages actions in particular might interfere with states' fiscal planning. ${ }^{131}$ This is of course true, but also provides no independent normative grounds for opposing meritorious suits; by the hypothesis of federal supremacy, the interference is deserved. ${ }^{132}$ To illustrate: states could not persuasively protest on sovereignty grounds a congressional decision to increase the budget and staff of the Department of Justice's civil fraud division 100 -fold or create a special division focusing exclusively on fraud by state entities; nor could states protest a presidential proclamation that policing state fraud is the Department's highest priority - even though each of these decisions might dramatically increase suits for damages against states, more so even than qui tam authorization. Simply put, state sovereignty does not implicate the question how often federal laws are enforced against states through meritorious suits.

We can also put aside a potential concern about meritless litigation against states. Such suits burden states through litigation costs and planning interruptions, and by hypothesis are not justified as valid attempts to secure the supremacy of federal law. But any claim that private suits are more likely to be meritless or even frivolous than executive form suits turns on the specific litigation incentive structure rather than the public/private status of the plaintiff. Unlike public prosecu-

an executive official would pursue (for example, where the suit seems meritorious but the gains too small to justify the deployment of scarce public resources). And there might be some suits that only an executive official but not a private relator would pursue (for instance, where the costs of prosecution are high and the likely monetary recovery is relatively small, but where the deterrence value of the suit is great). It is therefore speculative to compare a private-enforcement-only to a public-enforcement-only regime.

But for present purposes the more appropriate comparison is between a publicenforcement-only regime and a public-plus-private-enforcement regime. The dualenforcement regime would almost certainly generate more lawsuits (against all defendants, including states) than either enforcement regime by itself.

129. Alden, 119 S. Ct. at 2264.

130. Id. at 2266. By conceding that Congress may in some realms define and punish state misconduct (as the Court must, short of overruling Garcia v. San Antonio Metropolitan Transit Authority, 469 U.S. 528 (1985), and holding regulation of states entirely beyond Congress's Article I power), the Court necessarily concedes that state autonomy may validly be circumscribed. In any event, the availability of injunctions in private suits, see supra note 26 and accompanying text, means that damages suits cannot truly be feared on this basis.

131. See Alden, 119 S. Ct. at 2264-65.

132. The False Claims Act provides a clear case-in-point: surely a state cannot persuasively complain that a suit to recover funds the state itself defrauded from the Federal Treasury is an unwarranted interference with its control over its own treasury! 
tors, private litigants (and their lawyers) face the prospect of personal economic gain from successful False Claims Act litigation. But, also unlike public prosecutors, private litigants face the prospect of personal economic loss from unsuccessful and particularly frivolous suits, both because civil litigation is extremely costly and because frivolous suits invite monetary and other sanctions. ${ }^{133}$ Depending on how the incentives and disincentives are adjusted, a private enforcement regime may well lead to fewer meritless suits. And certainly a private enforcement regime may lead to more meritorious suits; indeed, Congress's rationale for revitalizing the False Claims Act's qui tam provisions was that the executive branch by itself was underenforcing federal law because it lacked the resources to detect violations or prosecute them once detected.

Instead, perhaps the Court's comment that the "National Government must itself deem the case of sufficient importance to take action against the State" ${ }^{" 134}$ reflects a focus on the process rather than the fact or result of litigation against states. When deciding whether to sue a state, the Court might surmise, a private plaintiff will focus primarily on financial variables, as well as other personal concerns such as time, stress, and publicity; she is not likely to worry about the burden her suit will impose on her state opponent. By contrast, a "politically responsible" official will more likely consider the putative state defendant's interest when deciding how to allocate scarce federal enforcement resources.

Is such speculation justified? It does seem quite reasonable to assume that federal officials exercising prosecutorial discretion will take into account national interests that might counsel against litigation; ${ }^{135}$ such interests are commonly and properly considered by prosecutors whose professional loyalty runs to their employer, the federal government. But federal prosecutors have no duty of loyalty to states per se, and thus it seems dubious that they would refrain from initiating an otherwise promising suit out of an abstract respect for the state's dignitary interests.

Perhaps a more plausible claim is that federal prosecutors are

133. See, e.g., False Claims Act, 31 U.S.C. $\$ 3730(d)(4)$ (1994) (court may award defendant fees and expenses if defendant prevails and action "was clearly frivolous, clearly vexatious, or brought primarily for purposes of harassment"); FED. R. CIV. P. 11 (sanctions for unjustified initiation or continual prosecution of suit). See generally John C. Coffee, Jr., Rescuing the Private Attorney General: Why the Model of the Lawyer as Bounty Hunter is Not Working, 42 MD. L. REV. 215, 226 (1983) (stating that private attorneys are unlikely to pursue costly litigation absent substantial likelihood of victory).

134. Alden, 119 S. Ct at 2269.

135. Particular suits might, for example, undermine national security or foreign policy interests, or reveal embarrassing information about federal bureaucratic ineptitude. See Caminker, supra note 16, at 366 (noting that a public prosecutor "would be likely to take these [types of] competing concerns more seriously than would many private litigants seeking pecuniary gain"). 
more likely than private plaintiffs to consider the concrete collateral consequences of imposing liability on a putative defendant in a specific case, including a state defendant. This consideration fits comfortably with a "public interest" fealty, as in some cases the defendant's interests are properly considered part of the larger public interest. A prosecutor might, for example, refrain from pursuing a viable claim against a defendant because of the harshness of a damages award under the circumstances (maybe the defendant is especially vulnerable financially, or maybe the alleged misconduct seems minor or hypertechnical in nature). There is no reason to think states would be granted any special solicitude as compared to private defendants, but both might gain some consideration for their plight from executive as compared to private law enforcement. But here again an official's hesitation would be counseled by an assessment of the overall public interest, not by any consideration of a state's sovereignty interests per se. Moreover, Congress's decision to authorize qui tam suits in a limited context reflects its considered judgment that the overall public interest would be better served by more aggressive False Claims Act enforcement than by enforcement from public prosecution alone. Because Congress has the authority to establish general enforcement priorities for the executive, ${ }^{136}$ the claim that the DOJ must be free to implement its own cost-benefit judgments about when to sue just because this would marginally and unintentionally reduce the number of suits against states seems quite weak.

Some lower court judges have proposed that states might exert political pressure against executive officials and thereby successfully forestall litigation. State officials might lobby the Attorney General or subordinate prosecutors directly, and the dissent in the Vermont decision even suggested that state officials might pressure their congressional representatives to lobby executive prosecutors on their behalf. ${ }^{137}$ The ability of this pressure to forestall suits, however, is highly

136. See, e.g., Heckler v. Chaney, 470 U.S. 821, 833 (1985) ("Congress may limit an agency's exercise of enforcement power if it wishes, either by setting substantive priorities, or by otherwise circumscribing an agency's power to discriminate among issues or cases it will pursue.").

137. See United States ex rel. Stevens v. Vermont Agency of Natural Resources, 162 F.3d 195, 219 (2d Cir. 1998) (Weinstein, J., dissenting) ("[A]ssigning the federal government's decision to sue a state to private qui tam plaintiffs - who are accountable to no one and motivated primarily by the hope of financial gain - prevents congresspersons from fulfilling their representative function of interceding on behalf of their home states in disputes with the federal government ...."), cert. granted, 119 S. Ct. 2391 (1999). This suggestion raises interesting separation of powers concerns. Those who support the notion of a unitary executive, and thus would be predisposed to favor the notion that prosecutorial discretion regarding suits against states should reside in executive officials rather than private litigants, should be quite troubled by the prospect of having members of Congress exert influence over the case-by-case exercise of that prosecutorial discretion. Cf., e.g., Morrison v. Olson, 487 U.S. 654, 698 (1988) (Scalia, J., dissenting) (expressing concern for the " 'gradual concentration of the several powers in the same department" " (quoting THE FEDERALIST, supra note 62, No. 51 (James Madison), at 321-22)). It is one thing for Congress to influence 
speculative. States (and their congressional representatives) do sometimes influence federal regulatory policy, but escaping from erstwhile legal liability strikes me as a more dubious prospect. State officials certainly will have a weak bargaining position, with no moral ground to stand on; they essentially will be requesting mercy for their own wrongdoing against the federal government. What bargaining chips they do have again seem unrelated to sovereignty interests per se. State officials might argue that a particular suit will undermine federal interests; and they might threaten federal executive officials with retaliation through some quid pro quo (for example, a refusal to participate in some federal program if the state is sued). But while both lobbying positions might reduce the quantity of suits against a state, neither does so in a manner that respects and secures the interests of state sovereignty underlying the immunity doctrine. ${ }^{138}$ Moreover, the substance of a False Claims Act violation renders reliance on such a "political safeguards" argument morally weak. The state cannot claim an interest in convincing a public prosecutor not to sue in order to avoid interference with state policy, since private individuals can sue for injunctive relief and thereby equally interfere with state policy. The only real issue here is whether the state will have to pay damages for past misconduct. In the False Claims Act context, the state would necessarily have to argue in favor of retaining monies wrongfully claimed from the Federal Treasury.

Even assuming arguendo that executive exercise of prosecutorial discretion would provide states with an additional buffer against being sued, there remains the question whether this forum for screening cases is persuasively viewed as constitutionally required on such functionalist federalism grounds. The Court has never previously suggested that states may be sued over an assertion of immunity only where both Congress and the executive branch believe such a suit is appropriate. Indeed, the Court has previously sanctioned executive branch suits against states despite the absence of specific, or some-

general enforcement priorities, either through legislation dictating such or through oversight hearings, budgetary allocations, and the like. It is a different and more troubling practice for Congress to exercise prosecutorial discretion in individual cases; this would allow Congress far more nuanced control over the actual application of its statutes, and hence afford it far greater power over the ultimate liberty of individual persons and entities.

138. The particular structure of the False Claims Act's qui tam provisions makes reliance on such a "political safeguards" argument even more empirically suspect. The Act requires qui tam relators to file their complaint under seal, and it is not served on the defendant during the Department of Justice's investigation determining whether it wants to play the lead role in the prosecution. Suppose the DOJ does decide to take over the litigation; typically, a state does not even know it is under investigation until that time. The state therefore cannot easily lobby the DOJ (either directly or indirectly through congressional pressure) until the decision has already been made. Surely, though, the DOJ's decision to intervene is not unconstitutional merely because the state lacked some requisite opportunity to importune state prosecutors. 
times any, congressional authorization to do so. ${ }^{139}$ Such nonstatutory executive standing typically involves suits to vindicate proprietary interests through common law claims, for instance, contract and boundary disputes, ${ }^{140}$ but the Court has upheld United States standing under certain circumstances to pursue "public interest injunctions" absent congressional authorization as well. ${ }^{141}$ The Court has never intimated that such suits against states fail to qualify for the US/p plan waiver even though states lose the benefit of the buffer of congressional screening in addition to executive screening. If the executive screen standing alone is sufficient to meet federalism concerns, then why not the congressional screen standing alone, when Congress is generally thought far more politically responsive to state interests than is the executive branch? ${ }^{142}$

Finally, Congress's indisputable authority to set enforcement priorities for the executive branch ${ }^{143}$ satisfactorily responds to the claim that qui tam suits "impede[] the successful functioning of our federal system" by undermining the cooperative relationships between state regulatory agencies and their federal counterparts. ${ }^{144}$ Congress is entitled to decide that zealous enforcement of the False Claims Act against state entities trumps the importance of smooth relations between states and the executive branch.

In the end, the argument intimated by Alden's cryptic equation of

139. See, e.g., Pennsylvania v. Union Gas Co., 491 U.S. 1, 11 (1989) ("Indeed, this Court has [held] that no explicit statutory authorization is necessary before the Federal Government may sue a state."); United States v. California, 332 U.S. 19, 26-28 (1947) (allowing the Attorney General to litigate the United States' rights in submerged land of California, even though Congress had twice refused expressly to authorize such a suit). See generally Henry P. Monaghan, The Protective Power of the Presidency, 93 CoLUM. L. Rev. 1, 66 (1983) (arguing that the "protective power" of the presidency "includes the general right of the executive, without express statutory authority, to make contracts and, more importantly, to sue to protect the personnel and property interests of the United States, and when necessary to use force and other resources to protect them").

140. See United States v. Solomon, 419 F. Supp. 358, 363 (D. Md. 1976) (citing early cases), affd, 563 F.2d 1121 (4th Cir. 1977).

141. See, e.g., Sanitary Dist. v. United States, 266 U.S. 405 (1925) (upholding executive's nonstatutory standing to seek an injunction prohibiting Illinois from diverting water from Lake Michigan); In re Debs, 158 U.S. 564 (1895) (upholding executive's nonstatutory standing to seek an injunction against a labor strike); United States v. San Jacinto Tin Co., 125 U.S. 273 (1888) (upholding executive's nonstatutory standing to bring equity action to annul a land patent).

142. For a different challenge to the executive-screen thesis along functionalist lines, see Siegel, supra note 11, at 561-63 (arguing that because Congress may validly circumscribe executive prosecutorial discretion, for instance, by requiring Department of Justice officials automatically to bring suit whenever a relator refers a case to them, independent executive exercise of prosecutorial discretion cannot be constitutionally required).

143. See supra note 136 and accompanying text.

144. United States ex rel. Stevens v. Vermont Agency of Natural Resources, 162 F. 3d 195, 225, 226-228 (2d Cir. 1998) (Weinstein, J., dissenting), cert. granted, 119 S. Ct. 2391 (1999). 
suits by the United States and executive form suits rests on both questionable empirical and normative grounds. For a functionalist, these concerns might well provide sufficient reason to reject the linkage. ${ }^{145}$ But as I argue in the next Section, given the Court's previous methodological approach to sovereign immunity doctrine, one would expect the Court to reject the equation between United States suits and executive form suits because the argument assumes a methodological commitment - bowing to contemporary functionalist concerns - that the Court has elsewhere expressly eschewed.

\section{A Reconstructionalist Approach to Litigation Form in Suits by the United States}

Recall the Court's vision in Monaco and Blatchford of a mutual waiver pact, negotiated by the several states and the United States at the time of the framing, to enable the United States to enforce peaceably its independent sovereign and proprietary interests against each of the member states for the common benefit of all. According to this reconstruction of the original understanding, the states were focused on the type of interest being asserted against them in a given case rather than on the structural form of litigation.

But even if one believes the states would have focused on form as well as substance, presumably at the very least (in the absence of any specific indication to the contrary) they would have consented to suit by the United States through the forms of litigation then prevalent. It may be one thing to ask whether states should be deemed to have waived their immunity from a novel form of suit that had not yet been conceived of 200 years ago. It is quite another, however, to refuse to recognize a waiver for a form widely employed by the Founding generation, and moreover to demand affirmatively a form that was, at least in full dress, quite foreign to this nation's early experience.

To begin with, "[s]tatutes providing for actions by a common informer, who himself has no interest whatever in the controversy other than that given by statute, have been in existence for hundreds of years in England, and in this country ever since the foundation of our Government."146 This form of action developed in postmedieval England, first based on common law proceedings and later authorized by various statutes. ${ }^{147}$ The American colonies and early states patt-

145. Moreover, even if one embraces the equation on functionalist grounds, the supervisory and potentially supplanting role of the Department of Justice in qui tam suits under the False Claims Act satisfies the functional concerns on their own terms. See infra text accompanying notes 181-83.

146. United States ex rel. Marcus v. Hess, 317 U.S. 537, 541 n.4 (1943) (citation omitted).

147. See, e.g., 1 MATTHEW BACON, ABRIDGEMENT OF THE LAW 73-86 (1832) (discussing various aspects of statutory authorization and facilitation of qui tam actions in 17th-18th century England); Note, The History and Development of Qui Tam, 1972 WASH. U. L.Q. 81, 
erned much of their law enforcement efforts on this English convention. ${ }^{148}$ Because state governments frequently authorized qui tam relators to pursue their own interests, it is difficult to deny that states would have expected the national government to do the same.

And this expectation would have been fulfilled. The first Congress, constituted of many of the leading Framers, enacted legislation both authorizing and facilitating qui tam actions. ${ }^{149}$ Subsequent early Congresses continued to expand qui tam authorization, ${ }^{150}$

83-91, 90 (describing English history of common law and statutory qui tam actions, concluding that "in the seventeenth century the qui tam concept had wide acceptance in England").

148. See, e.g., Steven L. Winter, The Metaphor of Standing and the Problem of SelfGovernance, 40 STAN. L. REV. 1371, 1406 (1988) ("The colonies and the states employed informers' statutes in a wide variety of cases, including the enforcement of regulatory statutes and morals legislation"); id. at 1406-07 \& nn.189-91 (providing examples of state qui tam statutes); Raoul Berger, Standing to Sue in Public Actions: Is It a Constitutional Requirement?, 78 YALE L.J. 816, 825-27 (1969) (highlighting early history of qui tam actions in pre- and postrevolutionary America); Krent, supra note 46, at 296-303 (observing that the early American employment of qui tam actions was designed to supplement public criminal law enforcement); The History and Development of Qui Tam, supra note 147, at 94 ("There are, however, numerous examples of statutory qui tam in early American history. Many colonies expressly adopted in toto certain English statutes which could be enforced by qui tam procedures. In addition, other statutes were adopted with minor modifications. Moreover, American legislatures did use qui tam provisions similar to those found in English statutes."); id. at 95 ("Statutes providing for qui tam suits were common in eighteenth century America....").

149. The first Congress employed qui tam actions in various forms and contexts. Six statutes imposed penalties and/or forfeitures for conduct injurious to the general public and expressly authorized suits by private informers, with the recovery being shared between the informer and the United States. See Act of Mar. 1, 1790, ch. 2, § 3, 1 Stat: 101, 102 (marshals' misfeasance in census taking); Act of July 5, 1790, ch. 25, § 1, 1 Stat. 129 (same); Act of July 20,1790 , ch. 29, $\$ 4,1$ Stat. 131, 133 (harboring runaway mariners); Act of July 22, 1790, ch. 33, § 3,1 Stat. 137, 137-38 (unlicensed Indian trade); Act of Feb. 25, 1791, ch. 10, \$\$ 8, 9, 1 Stat. 191, 195-96 (unlawful trades or loans by Bank of United States subscribers); Act of Mar. 3, 1791, ch. 15, § 44, 1 Stat. 199, 209 (avoidance of liquor import duties).

Three statutes similarly imposing penalties and/or forfeitures for conduct injurious to the general public authorized informers bringing successful prosecutions to keep the entire recovery. See Act of July 31,1789 , ch. 5, $\$ 29,1$ Stat. 29, 44-45 (import duty collectors' failure to post accurate rates); Act of Sept. 1,1789, ch. 11, §21, 1 Stat. 55, 60 (failure to register vessels properly); Act of Aug. 4, 1790, ch. $35, \S 55,1$ Stat. 145, 173 (import duty collectors' failure to post accurate rates).

Two other qui tam statutes imposed penalties and/or forfeitures for conduct injurious both to the general public and more concretely to a subclass thereof. One allowed any person to sue, see Act of July 20,1790, ch. 29, $\$ 1,1$ Stat. 131, 131 (failure of vessel commander to contract with mariners); and the other allowed suits by anyone whose private rights were violated, see Act of May 31, 1790, ch. 15, § 2, 1 Stat. 124, 124-25 (copyright infringement).

Congress conferred federal jurisdiction over qui tam actions in the first Judiciary Act of 1789 , ch. 20, $\$ 9,1$ Stat. 73, 76-77 (authorizing federal district jurisdiction "of all suits for penalties and forfeitures incurred, under the laws of the United States").

150. See, e.g., Act of Mar. 22, 1794, ch. 11, $\S 2,4,1$ Stat. 347, 349 (prohibiting slave trading from the United States to any foreign country); Act of May 8, 1792, ch. 36, § 5, 1 Stat. 275,277 (providing rules for awarding costs in cases brought by "any informer or plaintiff on a penal statute to whose benefit the penalty or any part thereof if recovered is directed by law").

Professor Harold Krent has reported that "[w]ithin the first decade after the Constitution was ratified, Congress enacted approximately ten qui tam provisions authorizing indi- 
and as late as the turn of this century, the Supreme Court recognized that the "right to recover the penalty or forfeiture granted by statute is frequently given to the first common informer who brings the action, although he has no interest in the matter whatever except as such informer." 151 This "early congressional practice" more than "provides 'contemporaneous and weighty evidence of the Constitution's meaning," "152 thus confirming the constitutionality of the enforcement regime in general. It also establishes a strong presumption that states would have assumed that their immunity waiver for suits by the United States encompassed qui tam suits on behalf of the United States.

Moreover, and directly contrary to the Blatchford and Alden dicta equating suits by the United States with those prosecuted by politically accountable public officials, the Founding generation evidenced little if any concern that prosecutors of federal law violations be politically accountable to any centralized federal authority. ${ }^{153}$ The primary federal prosecutors were district attorneys (essentially the precursors of today's U.S. Attorneys). Due to the lack of hierarchical organization, they were quite isolated from one another and for all practical purposes were not meaningfully responsible to the President, the Attorney General, or any other highranking executive officer. ${ }^{154}$ The Attorney General's primary duty was

viduals to sue under criminal statutes." Krent, supra note 46 , at 296 . He noted that this "number is particularly significant given the relative paucity of criminal provisions passed by Congress." Id. at 296 n.104. See generally Adams v. Woods, 6 U.S. (2 Cranch) 336, 341 (1805) ("Almost every fine or forfeiture under a penal statute, may be recovered by an action of debt [by qui tam plaintiffs] as well as by information [by the public prosecutor].").

151. Marvin v. Trout, 199 U.S. 212, 225 (1905).

152. Alden v. Maine, 119 S. Ct. 2240, 2261 (1999) (quoting Printz v. United States, 521 U.S. 898, 905 (1997)).

153. Neither were state prosecutors generally politically accountable. See Allen Steinberg, From Private Prosecution to Plea Bargaining: Criminal Prosecution, the District Attorney, and American Legal History, 30 CRIME \& DELINQ. 568 (1984) (detailing extensive role of private prosecutors in state law enforcement throughout colonial and early constitutional periods, and demonstrating that the fundamental transformation from a private-enforcement-dependent to a mostly public-dependent law enforcement regime took place in the mid-nineteenth century).

154. See, e.g., LEONARD D. WHITE, THE FEDERALISTS 406, 408 (1948) (describing how federal district attorneys were subject to the supervision of the Secretary of State rather than the Attorney General, and how they "apparently received no standard instructions, nor did they render annual or other regular reports. Apart from cases of exceptional importance and difficulty, they operated largely on their own responsibility ..."); Abraham S. Goldstein, History of the Public Prosecutor, in ENCYClOPEDIA OF CRIME AND JuSTICE 1286, 1287 (Sanford H. Kadish et al. eds. 1983) ("Not until the Civil War broke out in 1861 did Congress give the attorney general 'superintendence and direction of United States Attorneys.' "); Lawrence Lessig \& Cass R. Sunstein, The President and the Administration, 94 COLUM. L. REV. 1, 16-17 (1994) ("[The Judiciary Act of 1789] created district attorneys who prosecuted suits on behalf of the United States in the district courts. Until 1861, however, these district attomeys did not report to the Attorney General, and were not in any clear way answerable to him. Before 1861, the district attorneys reported either directly to no one 
providing legal advice to other executive officials, ${ }^{155}$ and he also represented the United States in litigation before the Supreme Court. ${ }^{156}$ Furthermore, the enforcement regime was highly reliant on supplementation by private counsel, even leaving qui tam relators aside. ${ }^{157}$ This patchwork pattern of law enforcement belies a claim that the Framers placed a high priority on the political accountability of public prosecution. ${ }^{158}$ Whatever the Framers' views of the concept of a unitary executive in general (about which there is wide division), it was not realized in fact with respect to law enforcement through federal litigation. ${ }^{159}$

(1789 to 1820) or to the Secretary of the Treasury (1820 through 1861). Throughout this period, they operated without any clear organizational structure or hierarchy." (footnotes omitted)); Stephanie A.J. Dangel, Note, Is Prosecution a Core Executive Function? Morrison v. Olson and the Framers' Intent, 99 YALE L.J. 1069, 1085 (1990) ("The Attorney General did not have supervisory charge of the United States attorneys, the primary prosecutors at this time...."); id. ("[C]ontacts between the district attorneys and the Department of State were 'largely fortuitous.' In general, the district attorneys conducted prosecutions for federal officials on a fee basis."(citation omitted)).

155. See Charles Tiefer, The Constitutionality of Independent Officers as Checks on Abuses of Executive Power, 63 B.U. L. REV. 59, 75 (1983) ("The Attorney General did not control or supervise federal district attorneys; his function was merely to advise the President and the Cabinet.").

156. See Act of Sept. 24, 1789, ch. 20, § 35, 1 Stat. 73, 93.

157. Before the Department of Justice's creation in 1870 , private attorneys frequently handled the federal government's cases. See LINCOLN CAPLAN, THE TENTH JUSTICE 4-5 (1987) (explaining that the DOJ's creation was responsive to widespread dissatisfaction with the way private attorneys handled the public's cases); see also, e.g., Dangel, supra note 154, at 1083 ("Federal departments and local officers routinely resorted to hiring private attorneys as 'special counsel' to prosecute government cases.").

158. See Lessig \& Sunstein, supra note 154, at 19-20 ("[F]ederal prosecutorial authority was also granted to private individuals wholly outside the executive's control. Both through citizen access to federal grand juries, and through civil qui tam actions (treated for at least some purposes as criminal actions), citizens retained the power to decide whether and in what manner to prosecute for violations of federal law." (citations omitted)); Daniel N. Reisman, Deconstructing Justice Scalia's Separation of Powers Jurisprudence: The Preeminent Executive, 53 ALB. L. REV. 49, 58 (1988) ("In the period after the framing of the Constitution, therefore, federal law enforcement powers were dispersed among private individuals, state officials, and largely independent United States district attorneys.").

159. One might wonder whether the ubiquity of qui tam enforcement against private defendants is largely beside the point, because the states might have assumed that they would be party defendants only in the Supreme Court's original jurisdiction, and that an executive branch official would be responsible for litigating cases at the Court even if in no other court. (As it turned out, the Judiciary Act of 1789 authorized the Attorney General to represent the United States in litigation before the Supreme Court. See supra text accompanying note 156.) But such an assumption of suability only in the Court's original jurisdiction would be quite tendentious, for each of several reasons. First, neither Article III nor the Judiciary Act of 1789 provided textual authority for the Court's exercise of original jurisdiction in a dispute between the United States and a member state; such jurisdiction was not statutorily granted until 1948, well after the decision in Texas. See Act of June 25, 1948, ch. 646, 62 Stat. 927 (codified as amended at 28 U.S.C. \$ 1251 (b)(2) (1994)). Second, while there is some historical support for the notion that states would be suable by the United States in the Court's original jurisdiction, see supra note 80, as explained earlier the Court certainly had to struggle somewhat to provide an analytical foundation for this claim, thus at least rendering the issue ambiguous. See supra Part III.A. Third, there is no clear basis for 
This historical description of state and federal law enforcement highlighting a plethora of deployed law enforcement mechanisms generates a couple of specific conclusions about the Framers' likely views about litigation form. It is difficult to deny that the Founding generation would have contemplated qui tam actions against states since qui tam was a prevalent law enforcement mechanism, particularly absent any protest to the contrary. ${ }^{160}$ And it is equally difficult to insist that the Framers would have conceded state suability only by centrally organized and politically accountable officials, an organizational pattern that was simply absent at the Founding and that only emerged slowly and sporadically over a period of fourscore years.

But more generally, given the focus of the Court's historical exegesis and established methodology of the US/p plan waiver on litigation substance rather than form, it would be inappropriate to limit the scope of the plan waiver even to those several forms of litigation commonplace during the Founding era. The rationales for waiver apply whenever the litigation on behalf of the United States asserts a core sovereign or proprietary interest of the federal government, so long as the litigation form - whether old or novel, widespread or idiosyncratic - comports with all relevant constitutional requirements such that it lies within Congress's authority to employ. Even if the predominant means of asserting the United States' interests against states change over time, the waiver for litigation asserting those interests should remain steadfast.

Indeed, deciding today that a constitutional mode of litigating the United States' interests no longer qualifies for the US/p waiver would be akin to the Court's having decided in McKesson that the states' original waiver of immunity from Supreme Court appellate review was limited to the form of appellate review then envisioned and practiced.

states to have assumed that any such original Supreme Court jurisdiction would be exclusive of (rather than concurrent with) original lower court jurisdiction, where qui tam enforcement would have been reasonably expected to be the norm. See Judiciary Act of 1789, ch. $20, \S 13,1$ Stat. $73,80-81$ (providing that Court's original jurisdiction was exclusive in part but concurrent in part); Ames v. Kansas, 111 U.S. 449, 469 (1884) (recognizing that Congress may authorize lower federal courts to take original cognizance of controversies assigned by Article III to the Supreme Court's original jurisdiction); $c f .28$ U.S.C. $\$ 1251$ (b)(2) (providing for original but not exclusive jurisdiction over all controversies between the United States and a State).

Fourth and most significantly, qui tam actions to enforce federal statutory directives would necessarily present federal claims. Texas's short-lived wrong turn aside, the Court's original jurisdiction was never understood to encompass suits that fell within Article III jurisdiction for reasons (such as they arise under federal law) other than that a state is a party. See supra note 60 and accompanying text.

160. The Framers' silence on this point cannot cut against including qui tam suits in the US/p waiver, $c f$. Alden v. Maine, 119 S. Ct. 2240, 2260-61(1999) (arguing that silence reaffirmed the prior understanding that states were immune from suit absent consent), because the entire waiver issue was initially generated by the Constitution and thus there was no default understanding whose silent maintenance can be assumed. 
The McKesson Court did not tie the scope of the waiver to the original method of judicial nomination and confirmation (which was subsequently modified to the detriment of state control by the Seventeenth Amendment ${ }^{161}$ ), or to the prevailing practice of "riding circuit" (which arguably kept the Justices more in touch with regional and local interests), or any other aspect of judicial form. The Court did not even ponder these possibilities, instead applying the waiver to the function of Supreme Court review, in whatever form that review would eventually take given a changing constitutional and statutory landscape. ${ }^{162}$ What matters in immunity doctrine are the interests served by a waiver, not the precise method of selection or practices of the court or prosecutor involved.

\section{Conflicting Methodologies: Originalism Versus Functionalism}

To exalt the functional value of executive branch review of suits against states to the level of a constitutional requirement, the Court would have to break from its proclaimed commitment to reconstructing the Framers' original understanding of state suability. Of course, the Court has acknowledged that various immunity principles and counterprinciples were designed with particular federalism values in mind. On occasion the Court has described specific aspects of immunity doctrine as reflecting a "balance" between the states' sovereign prerogatives and Article VI's mandate of federal supremacy, ${ }^{163}$ and more generally the Court has proclaimed that "[t]he principle of sovereign immunity as reflected in our jurisprudence strikes the proper balance between the supremacy of federal law and the separate sovereignty of the States."164 However, despite its methodological plausibility, ${ }^{165}$ the Court has eschewed direct reliance on interest balancing

161. In the original Constitution, Justices were subject to the requirement of confirmation by a Senate whose members were selected by the several state legislatures. See U.S. CoNST. art II, § 2, cl. 2. After the Seventeenth Amendment, Justices became subject to confirmation by a popularly elected Senate. See U.S. CONST. amend. XVII.

162. In fact, excluding qui tam actions from the US/p waiver would be even more methodologically disturbing than this $M c K e s s o n$ hypothetical. At least the hypothetical limits the appellate review waiver to the form prevailing at the Founding and excludes the contemporary form. It would be far more disturbing within an originalist framework to exclude the form prevailing at the Founding and require instead the more contemporary form.

163. See, e.g., Idaho v. Coeur d'Alene Tribe, 521 U.S. 261, 270-80 (1997) (describing the Ex parte Young doctrine thusly); Pennhurst State Sch. \& Hosp. v. Halderman, 465 U.S. 89, 105 (1984) (same).

\section{Alden, 119 S. Ct. at 2268.}

165. See, e.g., Ann Althouse, When to Believe a Legal Fiction: Federal Interests and the Elẹventh Amendment, 40 HASTINGS L.J. 1123 (1989) (discussing interest-balancing in immunity doctrine); Evan H. Caminker, Context and Complementarity Within Federalism Doctrine, 22 HARV. J.L. \& PUB. POL'Y 161 (1998) (discussing notion of functionalism and interest-balancing in federalism doctrine). 
- particularly as measured by contemporary rather than Founding perspectives on interests - as a method of articulating the precise contours of immunity doctrine. ${ }^{166}$ The Court has pointedly not asked whether various aspects of state sovereign immunity, or even the concept in its entirety, make sense in the modern world of expansive federal regulatory power; rather, the Court has insisted that the means through which this power is asserted and enforced conform to its view of the Framers' original understanding as embedded within the constitutional plan. Grafting an executive form requirement onto the US/p plan waiver doctrine would necessarily reflect a methodological shift from originalism to functionalism, at odds with the Court's claimed basis for the legitimacy of this entire realm of nontextual doctrine. ${ }^{167}$

\section{The United States-as-Plaintiff Waiver and the False Claims Act's Qui Tam Provisions}

Based on the foregoing analysis, qui tam actions enforcing the False Claims Act should fall within the states' waiver of immunity in the constitutional plan for suits by the United States. The first critical factor is that, from several different perspectives, the United States is a real party in interest even in a qui tam action. First, Congress demonstrated such an intent by requiring every qui tam action to be filed "in the name of the Government." 163 Second, there is only one cause of action generated by any particular instance of fraud, and it belongs to the United States. No matter whether the first suit is brought by the Department of Justice or a relator, claim preclusion bars subsequent suits by either public or private prosecutors. ${ }^{169}$ And this singular cause of action is occasioned by an injury to the United States itself. When a person submits a false claim for payment as defined by the Act, it is the United States and not any relator who is directly injured thereby, as the fraudulently obtained money is siphoned from the Federal Treasury. ${ }^{170}$ Third, either the entire monetary recovery or the predominant share thereof accrues to the United States. Just as finan-

166. In Alden, for example, the Court pointedly ignored the dissent's counter-originalist claim that "past practice, even if unbroken, provides no basis for demanding preservation when the conditions on which the practice depended have changed in a constitutionally relevant way." Alden, 119 S. Ct. at 2290 (Souter, J., dissenting); id. at 2291 (arguing that the growth and recognition of congressional authority to impose at least generally applicable obligations directly upon states undermines the majority's originalist claims).

167. See supra notes $93-96$ and accompanying text.

168. 31 U.S.C. $\$ 3730(b)(1)$ (1994).

169. See id. at $\S 3730(\mathrm{~b})(5)$; Caminker, supra note 16 , at 354 n.71.

170. To be sure, if the qui tam plaintiff is a federal taxpayer, then she suffers an indirect (albeit minute) monetary injury. And as a U.S. citizen or legal resident, she suffers a derivative injury by virtue of the fact that the national government will be capable of providing fewer public services. But the injury that gives rise to the cause of action is clearly the primary injury to the United States itself. 
cial responsibility is a significant, indeed the predominant, factor in defining the scope of a government defendant's immunity, ${ }_{171}^{1 t}$ equally should manifest the sovereign interest of a government plaintiff. To paraphrase the Court, "[w]hen the action is in essence one for the recovery of money [to] the [United States], the [United States] is the real, substantial party in interest and is entitled to invoke its [sovereignty to bring] suit [against a state] even though individual [persons] are nominal [plaintiffs]."172 Perhaps even some lesser combination of factors would be enough, but these factors taken together make clear that the United States has its own sovereign and proprietary interests at stake in any False Claims Act suit. ${ }^{173}$

Moreover, the specific nature of the United States' interests fits comfortably within even the specific rationales for the US/p plan waiver outlined above. The United States has suffered an injury to a tangible asset, its treasury, not unlike the sovereign and proprietary injuries it would suffer if a state claimed ownership to and took possession of heretofore federal lands. And False Claims Act suits are also comfortably viewed as policing mutually incurred state obligations. One state's fraudulent diminution of the Federal Treasury imposes externalities on other states by redirecting funds meant to benefit the whole for the sole use of a part, essentially making maintenance of the national government more costly for the law-abiding states. ${ }^{174} \mathrm{It}$ is entirely appropriate for the United States to prevent one state from unfairly imposing such a burden on her sisters. Thus, the range of interests supporting the United States' invocation of the US/p plan waiver embraces False Claims Act suits on its behalf against states.

Indeed, this conclusion results even if one believes that Congress's power to authorize qui tam suits against states is narrower than its power to authorize executive branch litigation against states. As discussed earlier, ${ }^{175}$ there is an interesting question of whether the US/p

171. See, e.g., Regents of the Univ. of Cal. v. Doe, 519 U.S. 425,430 (1997) (stating that this factor is of "considerable importance"); Edelman v. Jordan, 415 U.S. 651, 663 (1974) (holding that suit "seeking to impose a liability which must be paid from public funds in the state treasury is barred"); CHEMERINSKY, supra note $18, \S 7.4$, at 388 (arguing that the question of whether judgment will be satisfied from state treasury is an "especially" important one).

172. Ford Motor Co. v. Department of Treasury, 323 U.S. 459, 464 (1945).

173. A number of lower courts have concluded that, for purposes of the US/p plan waiver, the United States is a real party in interest in qui tam litigation. See, e.g., United States ex rel. Berge v. Board of Trustees of the Univ. of Ala., 104 F.3d 1453, 1457 (4th Cir. 1997); United States ex rel. Hall v. Tribal Dev. Corp., 49 F.3d 1208, 1213 (7th Cir. 1995); United States ex rel. Kreindler \& Kreindler v. United Tech. Corp., 985 F.2d 1148, 1154 (2d Cir. 1993).

174. See supra note 90 and accompanying text; $c f$. McCulloch v. Maryland, 17 U.S. (4 Wheat.) 316 (1819) (invalidating Maryland's tax imposed on the Bank of the United States, observing that the benefit of the state tax accrued entirely to Maryland but the burden of the tax fell primarily on the rest of the states).

175. See supra Section III.B. 
waiver encompasses even public official suits against states where the United States is essentially vindicating a "nominal interest" on behalf of its citizens rather than a governmental interest of its own. Assuming arguendo the answer is yes, one might still separately question whether qui tam suits in such circumstances fall within the waiver. Where the "real party in interest" is private rather than the United States itself, qui tam authorization feels like something of a bootstrap; one might suspiciously view it as an effort to circumvent the Seminole Tribe/Alden rule that Congress cannot authorize private parties to assert their "own" interests against states. ${ }^{176}$

For present purposes, this intriguing question also needs no definitive answer. A qui tam suit to enforce the False Claims Act clearly asserts core sovereign and proprietary interests of the federal government, and thus falls into the "governmental interest" rather than "nominal interest" category. Where Congress authorizes a private relator to assert the interests of the United States itself, and a fortiori where the relator has no legal interest in the suit prior to her being the first-filing plaintiff, no similar concerns about bootstrapping over Seminole Tribe arise. Congress cannot be viewed here as cleverly "delegating back" to a private party authority to bring a claim that was already hers, albeit in a form barred by state sovereign immunity. Rather, Congress is providing the initial authority for the relator to advocate on behalf of the United States a set of governmental interests that quintessentially qualify for the US/p waiver. Even if one embraces a chary perspective of qui tam authorization in the immunity context, Congress's power to utilize this traditional scheme to assert the United States' legal interests against states encompasses suits enforcing the False Claims Act.

The fact that the qui tam relator is also defined as a "party" under the Act does not change the nature or diminish the extent of the United States' interest in the litigation. The private relator sues for

176. This perception sheds important light on the Court's dictum in Blatchford about the delegability of the United States' exemption from the state immunity defense. In this case, the plaintiff Indian tribe argued that it ought to be able to sue a state because the United States could sue on its behalf, and consequently the United States could delegate "back" to it the authority to sue the state directly. Before holding that Congress effected no such delegation, see Blatchford v. Native Village of Noatak, 501 U.S. 775, 785-86 (1991), the Court commented that,

We doubt, to begin with, that that sovereign exemption can be delegated - even if one lim-

its the permissibility of delegation (as respondents propose) to persons on whose behalf the

United States itself might sue .... [E]ven consent to suit by the United States for a particu-

lar person's benefit is not consent to suit by that person himself.

Id. at 785 (emphasis added). This last sentence suggests a concern for congressional bootstrapping, driving a plausible conclusion that the US/p waiver might encompass "nominal interest" suits only when brought by public officials but not the private real party in interest herself. This conclusion dovetails with other cases evidencing a concern for "shell game" suits where a government tries to maneuver around the real-party-in-interest test. See supra notes 105-12 and accompanying text (states cannot prosecute "nominal interest" suits against unconsenting state defendants). 
herself as well as the government in the sense that, once filed, the action itself gives her an inchoate interest in the outcome of the litigation. ${ }^{177}$ But this interest is both derivative and contingent. It is derivative in the sense that the primary underlying injury is not hers, but rather belongs to the United States. It is contingent in the sense that if she is not the first-filing plaintiff, then she never acquires any interest in the dispute. ${ }^{178}$ To be sure, if she is the first-filing plaintiff she then becomes a party to the litigation, perhaps even a real party in interest for some purposes. But the United States unquestionably remains a real party in interest as well, whose interests the suit purports to vindicate. $^{179}$

For reasons explained above ${ }^{180}$ moreover, the qui tam form of litigation provides no basis for excluding such suits from the US/p waiver. Absent specific indication to the contrary, it seems implausible that the Framers would specifically have rejected a commonplace enforcement mechanism in favor of the executive form which did not prevail until the mid-nineteenth century. More generally, the Framers most plausibly would have understood states to waive their immunity from suits by the United States through whatever forms Congress could constitutionally deploy at any given time.

In any event, even if an executive form requirement is grafted onto US/p waiver doctrine, the fact that the current rendition of the False Claims Act provides the Department of Justice with ample means to

177. See, e.g., 2 WILLIAM BLACKSTONE, COMMENTARIES *437 (" $[\mathrm{H}] \mathrm{e}$ that brings his action, and can, bona fide, obtain judgment first, will undoubtedly secure a title to it, in exclusion of everybody else. He obtains an inchoate imperfect degree of property, by commencing his suit but it is not consummated till judgment ...."). It is only in this inchoate sense that "by commencing the suit, the informer has made the popular action his own private action ...." Id.

178. This understanding dates back to the English qui tam tradition during the colonial period. See The History and Development of Qui Tam, supra note 147, at $84 \mathrm{n} .18$ ("The informer's rights to the penalty did not attach until the suit was instituted, whereupon his rights attached absolutely and to the exclusion of all other potential informers.").

179. Indeed, even if one views the relator as "sharing" a portion of the United States' monetary interest in the litigation (typically $15-30 \%$, determined only after-the-fact), this perspective does not preclude the relator from litigating even the shared portion on behalf of the United States. The relator can obtain no recovery above and beyond what the DOJ could obtain on the United States' behalf; her share merely reduces the amount recoverable by the United States that is ultimately returned to the Federal Treasury. The Court has previously held that the US/p plan waiver is not voided merely because a private party joins the United States in litigation when the private plaintiff seeks no greater relief than which is that already being sought. See Maryland v. Louisiana, 451 U.S. 725, 745 n.21 (1981) (summarily waiving aside Eleventh Amendment concerns when the United States, a federal agency, and private companies were allowed to intervene as plaintiffs in an original action between two states); Arizona v. California, 460 U.S. 605, 614 (1983) (allowing Indian tribes to intervene in a suit between two states in which the United States had already intervened on behalf of those tribes; citing Maryland v. Louisiana, the Court explained that because the tribes did not seek to raise any new claims, "our judicial power ... is not enlarged" and state "sovereign immunity ... is not compromised").

180. See supra Section III.C. 
monitor and take over privately initiated litigation against states should suffice. The Court in Alden expressed concern over the lack of political accountability occasioned by a "broad delegation" of litigation authority to private persons. ${ }^{181}$ But the delegation of authority to qui tam plaintiffs is significantly circumscribed. As explained earlier, DOJ officials may monitor the prosecution and, upon a showing of good cause, intervene and take over the lead prosecutorial role in representing the interests of the United States. Upon a proper showing the DOJ can even settle or dismiss the case over the relator's protest. ${ }^{182}$ Thus public officials can still consider and protect the state's abstract or tangible interests in avoiding liability, and they can still in theory be responsive to direct political pressure from state officials, or indirect pressure from the state's congressional representatives. One might even view a decision by the DOJ not to exercise its authority to take over the litigation as a voluntary and politically accountable relinquishment of its enforcement power to enable a specific individual (and her counsel) to advocate the interests of the United States. Therefore, even if some measure of executive prosecutorial discretion in suits against states is considered a necessary "political safeguard of federalism," the oversight role provided the DOJ in the False Claims Act would seem to satisfy this requirement. ${ }^{183}$

\section{CONCLUSION}

The Court's previous cases concerning the states' waiver in the constitutional plan of their erstwhile sovereign immunity have dealt with "exemplar" situations involving executive branch litigation on behalf of the United States. Vermont offers the Court an opportunity to clear up lower court confusion concerning whether the form of litigation matters, as opposed to its substance.

In so doing, Vermont places the Court at a methodological crossroads. Fidelity to its long-standing commitment to originalism in determining sovereign immunity doctrine suggests that the Court should apply the waiver to all suits brought by the United States through any constitutionally valid litigation form. The contrary conclusion could be reached only by embracing the functionalist argument that executive branch review provides a supplemental - and constitutionally requisite - "political safeguard of federalism" protecting states' interest in avoiding liability for their misconduct. The merit of this ar-

181. Alden v. Maine, 119 S. Ct. 2240, 2267 (1999) (emphasis added).

182. See supra notes $48-55$ and accompanying text. The fact that some showing is required does not itself trigger constitutional concerns. See Caminker, supra note 16, at 387 n.227.

183. See generally Caminker, supra note 16 , at $359-67$ (discussing executive oversight in greater detail). 
gument is debatable on its own terms. ${ }^{184}$ But its adoption would challenge the foundations of the underlying immunity principle itself, for the Court claimed legitimacy for its doctrinal pronouncements in Seminole and Alden based on their originalist pedigree. Thus the decision in Vermont may do more than resolve an interesting and important question concerning the scope of the US/p waiver; it may either reaffirm or redirect the Court's methodological approach to a broader array of sovereign immunity issues arising in the next millennium. 